\title{
Buku Ajar Mata Kuliah Ekonomi Pembangunan
}

\author{
Oleh \\ Rizky Eka Febriansah; Detak Prapanca
}

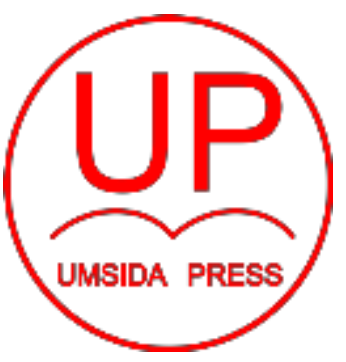

Diterbitkan oleh

UMSIDA PRESS

J1. Mojopahit 666B Sidoarjo

ISBN: 978-602-5914-76-8

Copyright $^{\circledR} 2019$.

\section{Authors}

All rights reserved 


\section{Buku Ajar \\ Ekonomi Pembangunan}

Penulis :

Rizky Eka Febriansah; Detak Prapanca.

\section{ISBN :}

978-602-5914-76-8

\section{Editor :}

Septi Budi Sartika, M.Pd

M. Tanzil Multazam, S.H., M.Kn.

Copy Editor :

Fika Megawati, S.Pd., M.Pd.

Design Sampul dan Tata Letak :

Mochamad Nashrullah, S.Pd

\section{Penerbit :}

UMSIDA Press

Redaksi :

Universitas Muhammadiyah Sidoarjo

Jl. Mojopahit No 666B

Sidoarjo, Jawa Timur

Cetakan pertama, Agustus 2019

(C) Hak cipta dilindungi undang-undang Dilarang memperbanyak karya tulis ini dengan suatu apapun tanpa ijin tertulis dari penerbit 



\section{KATA PENGANTAR}

Puji syukur kehadirat Allah SWT atas segala anugerah dan rahmat-Nya, sehingga Buku Ajar Pengantar Ekonomi Pembangunan jilid 1 untuk Fakultas Ekonomi dan Bisnis Universitas Muhammadiyah ini dapat terselesaikan dengan baik.

Buku Ajar Pengantar Ekonomi Pembangunan jilid 1 ini terdiri dari 6 Bab Materi Perkuliahan, yang merupakan satu kesatuan materi yang dipelajari oleh mahasiswa secara menyeluruh dan tak terpisahkan selama setengah semester / pertemuan sebelum UTS karena merupakan satu kesatuan yang utuh dalam Capaian Kompetensi dari Pengantar Ekonomi Pembangunan di Rencana Pembelajaran Semester .

Tujuan diterbitkan buku ajar ini untuk membantu mahasiswa agar dapat menguasai konsep dan perspektif pembangunan ekonomi dalam manajemen dan bisnis secara mudah, dan utuh. Di samping itu pula, buku ajar ini dapat digunakan sebagai acuan bagi dosen yang mengampu mata kuliah Pengantar Ekonomi Pembangunan. Isi modul ini memuat 5 komponen utama yaitu; Pendahuluan, Penyajian Materi, Rangkuman, Latihan dan Daftar Pustaka. Buku Ajar Pengantar Ekonomi Pembangunan jilid 1 Ekonomi dan Bisnis ini diterbitkan oleh Universitas Muhammadiyah Sidoarjo (UMSIDA) Press untuk kalangan sendiri. Buku Ajar ini merupakan buku terbitan edisi pertama yang tentunya masih butuh disempurnakan. Oleh karena itu, saran dan masukan oleh para pengguna sangat kami harapkan untuk kesempurnaan isi buku ajar ini di masa yang akan datang.

Sidoarjo, Juni 2019 


\section{DAFTAR ISI}

$\mathrm{BAB}$ I : Indikator pembangunan

A. Mengukur keberhasilan pembangunan 1

B. Indikator Moneter 3

C. Indikator Non Moneter 4

D. Indikator Campuran $\quad 7$

E. Karakteristik Umum Negara Sedang Berkembang 10

F. Pendapatan Nasional 19

G. Soal Soal 24

BAB 2 Teori Pertumbuhan dan Pembangunan Ekonomi...... 25

A. Pengelompokan teori 25

B. Mazhab Historismus 26

C. Mahzab Klasik 30

D. Mazhab Keynesian 34

E. Teori Pertumbuhan Neoklasik 36

F. Teori Pertumbuhan Endogen 38

G. Teori Schumpeter 40

H. Teori Ketergantungan 42

I. Soal Soal 44 
BAB 3: Strategi Pertumbuhan dan Pembangunan Ekonomi...45
A. Lingkaran Kemiskinan
B. Teori Kausasi Kumulatif
C. Teori Perangkap Keseimbangan Tingkat Rendah
D. Strategi Upaya Minimum Kritis
E. Strategi pembangunan Seimbang
F. Strategi Pembangunan Tak Seimbang
G. Soal Soal

A. Sejarah perekembangan perencanaan 64

B. Pengertian, unsur, dan fungsi perencanaan 65

C. Perlunya Perencanaan Ekonomi di Negara Berkembang 69

D. Proses perencanaan ekonomi 71

E. Perencanaan dan Sistem Ekonomi: Kapitalis $\quad 73$

F. Perencanaan dan Sistem Ekonomi: Sosialis $\quad 74$

G. Perencanaan dan Sistem Ekonomi: Campuran $\quad 75$

H. Perencanaan pembangunan di Indonesia $\quad 76$

I. Soal Soal 80

Bab 5 : tabungan dalam negeri.................. 81
A. Investasi dan pertumbuhan ekonomi
B. Sumber tabungan dalam negeri
84 
C. Faktor penentu tabungan swasta

D. Perkembangan sumber pembiayaan dalam negeri Indonesia $\quad 89$

E. Soal soal

BAB 6 : Sumber dana dari luar negeri................... 92

A. Bantuan Luar Negeri 92

B. Lembaga bantuan Internasional 94

C. Dampak bantuan luar negeri terhadap pembangunan 99

D. Manfaat investasi asing 100

E. Kebijakan NSB mengenai investasi asing 102

F. Sumber pinjaman luar negeri bagi pembangunan di Indonesia 104

G. Soal Soal 108 


\section{Indikator pembangunan}

\section{A. Mengukur Keberhasilan Pembangunan}

Pengertian pembangunan bisa menjadi sangat luas. Pembangunan ekonomi seringkali didefinisikan sebagai sesuatu proses kenaikan pendapatan riil perkapita dalam jangka panjang. Tetapi, kenaikan pendapatan saja belum cukup untuk dikatakan bahwa telah terjadi pembangunan ekonomi. Perbaikan struktur sosial, sistem kelembagaan, perubahan sikap dan perilaku masyarakat juga merupakan komponen penting dari pembangunan ekonomi.

Menurut Sadono Sukirno, ekonomi pembangunan merupakan proses usaha meningkatkan pemasukan atau pendapatan perkapita suatu Negara dengan cara mengolah potensi ekonomi menjadi bentuk riil. Hal tersebut dilakukan melalui 5 tahap penting, yaitu:

1. Penanaman modal,

2. Pemanfaatan teknologi,

3. Peningkatan pengetahuan, 
4. Pengelolaan keterampilan, dan

5. Penambahan skill berorganisasi

Menurut Lincolin Arsyad, ekonomi pembangunan adalah meningkatnya kemampuan suatu Negara untuk menyediakan beragam barang yang dibutuhkan penduduknya dalam jangka panjang. Kemampuan dapat meningkat seiring dengan berjalannya waktu dan hal tersebut terdiri dari 3 komponen, yaitu:

1. Peningkatan ketersediaan barang,

2. Kemajuan teknologi, dan

3. Penyesuaian kelembagaan atau ideologi yang menghasilkan ilmu pengetahuan.

Berdasarkan luasnya pengertian tentang pembangunan ekonomi, Lincolin Arsyad berpendapat bahwa diperlukan suatu indikator untuk mengukur tingkat kemajuan pembangunan ekonomi di suatu negara. Indikator tersebut dapat bersifat fisikal, ekonomi, sosial, dan politik.

Berikut adalah indikator keberhasilan pembangunan yang dikelompokkan menjadi beberapa indikator: (1) indikator moneter, (2) indikator non moneter, dan (3) indikator campuran. 


\section{B. Indikator Moneter}

Umumnya dalam mengukur indikator moneter dapat dilihat dari pendapatan per kapita sebuah negara dalam satu periode tertentu. Pendapatan per kapita adalah indikator atas kinerja perekenomian secara keseluruhan. Pendapatan perkapita merupakan indikator moneter atas setiap kegiatan ekonomi penduduk suatu negara.

Beberapa ekonom memandang bahwa pendapatan perkapita bukanlah indikator yang terbaik untuk mengukur kinerja pembangunan suatu negara; pembangunan bukan hanya meningkatkan pendapatan riil saja, tetapi harus disertai perubahan sikap dan perilaku masyarakat yang sebelumnya menghambat kemajuan ekonomi.

Kelemahan mendasar dari pendapatan per kapita sebagai sebuah indikator pembangunan terletak pada ketidakmampuannya untuk menggambarkan tingkat kesejahteraan masyarakat secara utuh. Faktor non ekonomi seperti adat istiadat, keadaan iklim dan alam sekitar, serta ada atau tidaknya kebebasan dalam melakukan tindakan merupakan faktor yang dapat menyebabkan perbedaan 
tingkat kesejahteraan di negara yang memiliki tingkat pendapatan per kapita yang relatif sama.

Adanya perbedaan nilai tukar ta uang juga mengakibatkan perbandingan tingkat pendapatan perkapita antara negara maju dan NSB selalu timpang, sehingga perbedaan tingkat kesejahteraan digambarkan jauh lebih besar daripada yang sebenarnya terjadi di antara kedua kelompok negara tersebut. Kesalahan dalam mengestimasi tingkat pendapatan per kapita di NSB disebabkan oleh adanya ketidaksempurnaan dalam metode perhitungan pendapatan per kapita. Ketidaksempurnaan tersebut disebabkan oleh:

1. Adanya masalah dalam menentukan jenis kegiatan yang harus dimasukkan dalam perhitungan pendapatan nasional.

2. Adanya kesulitan dalam mengkonversi nilai pendapatan perkapita dari mata uang suatu negara ke mata uang lainnya.

\section{Indikator Non Moneter}

Beckerman dalam international comparisons of real incomes (1966) mengelompokan metode perbandingan 
tingkat kesejahteraan negara berdasarkan non monetary rules menjadi 3 kelompok:

1. Membandingkan tingkat kesejahteraan di beberapa negara dengan memperbaiki metode yang digunakan dalam perhitungan konvensional.

2. Membuat penyesuaian dalam perhitungan pendapatan nasional dengan mempertimbangkan adanya perbedaan tingkat harga di setiap negara.

3. Membandingkan tingkat kesejahteraan tiap negara berdasarkan pada data yang bersifat non moneter, seperti jumlah kendaraan bermotor, tingkat elektrifikasi, konsumsi minyak, jumlah penduduk yang bersekolah, dsb.

Indikator non moneter yang digunakan Beckerman adalah:

1. Jumlah konsumsi baja dalam satu tahun $(\mathrm{kg})$

2. Jumlah konsumsi semen dalam satu tahun dikalikan 10 (ton)

3. Jumlah surat dalam negeri dalam satu tahun

4. Jumlah persediaan pesawat radio dikalikan 10

5. Jumlah persediaan telepon dikalikan $\mathbf{1 0}$ 
6. Jumlah persediaan berbagai jenis kendaraan

7. Jumlah konsumsi daging dalam satu tahun $(\mathrm{kg})$

Usaha lain dalam menentukan dan membandingkan tingkat kesejahteraan negara dilakukan pula oleh United Nations Research Institute for Social Development (UNRISD), sebuah badan PBB, menggunakan 18 indikator dalam studinya (10 indikator ekonomi dan 8 indikator sosial):

\begin{tabular}{|l|l|l|}
\hline $\begin{array}{l}\text { Tingkat harapan } \\
\text { hidup }\end{array}$ & Jumlah radio & $\begin{array}{l}\text { Konsumsi energi } \\
\text { per kapita }\end{array}$ \\
\hline $\begin{array}{l}\text { Konsumsi protein } \\
\text { hewani per kapita }\end{array}$ & $\begin{array}{l}\text { Jumlah kota yang } \\
\text { memiliki lebih dari } \\
\text { 20.000 ribu } \\
\text { penduduk }\end{array}$ & $\begin{array}{l}\text { Konsumsi listrik } \\
\text { per kapita }\end{array}$ \\
\hline $\begin{array}{l}\text { Presentase anak } \\
\text { anak yang } \\
\text { bersekolah dasar } \\
\text { dan menegah }\end{array}$ & $\begin{array}{l}\text { Presentasi laki laki } \\
\text { dewasa di sektor } \\
\text { pertanian }\end{array}$ & $\begin{array}{l}\text { Konsumsi baja } \\
\text { per kapita }\end{array}$ \\
\hline $\begin{array}{l}\text { Presentase anak } \\
\text { anak yang } \\
\text { bersekolah } \\
\text { kejuruan }\end{array}$ & $\begin{array}{l}\text { Presentase tenaga } \\
\text { kerja di sektor } \\
\text { listrik, gas, air, } \\
\text { kesehatan, } \\
\text { pengangkutan, } \\
\text { pergudangan, dan } \\
\text { telekomunikasi }\end{array}$ & $\begin{array}{l}\text { Produk } \\
\text { pertanian rata } \\
\text { rata dari pekerja } \\
\text { pria di sektor } \\
\text { pertanian }\end{array}$ \\
\hline $\begin{array}{l}\text { Jumlah surat } \\
\text { kabar }\end{array}$ & $\begin{array}{l}\text { Presentase tenaga } \\
\text { kerja yang } \\
\text { memperoleh gaji }\end{array}$ & $\begin{array}{l}\text { Nilai perkapita } \\
\text { perdagangan } \\
\text { luar negeri }\end{array}$ \\
\hline
\end{tabular}




\begin{tabular}{|l|l|l|}
\hline Jumlah telepon & $\begin{array}{l}\text { Presentasi PDB dari } \\
\text { industri manufaktur }\end{array}$ & $\begin{array}{l}\text { Pendapatan per } \\
\text { kapita produk } \\
\text { nasional Bruto }\end{array}$ \\
\hline
\end{tabular}

\section{Indikator Campuran}

Pada tahun 1992, Biro Pusat Statistik Indonesia mengembangkan indikator kesejahteraan yang disebut core susenas (susenas inti). Susenas merupakan indikator campuran yang terdiri dari indikator sosial dan ekonomi. Indikator ini memiliki aspek berikut:

1. Pendidikan, dengan indikator: tingkat pendidikan, tingkat melek huruf, tingkat pastisipasi pendidikan.

2. Kesehatan, dengan indikator: rerata hari sakit dan fasilitas kesehatan yang tersedia.

3. Perumahan, dengan indikator: sumber air bersih dan listrik, sanitasi, dan kualitas tempat tinggal.

4. Angkatan kerja, dengan indikator: partisipasi tenaga kerja, jumlah jam kerja, status pekerjaan

5. Keluarga berencana dan fertilitas, dengan indikator: penggunaan ASI, tingkat imunisasi, kehadiran tenaga kesehatan pada kelahiran, penggunaan alat kontrasepsi. 
6. Ekonomi, dengan indikator: tingkat konsumsi per kapita

7. Kriminalitas, dengan indikator: angka kriminalitas per tahun

8. Perjalanan wisata, dengan indikator: frekuensi perjalanan wisata per tahun

9. Akses ke media masa: jumlah surat kabar, jumlah radio, dan jumlah televisi.

Pada tahun 1990, United for Development Program (UNDP) juga telah mengembangkan indikator campuran yang kini dikenal sebagai Indeks Pembangunan Manusia atau IPM.

IPM digunakan untuk melakukan pemeringkatan kinerja pembangunan di berbagai negara di dunia. Berdasarkan indeks IPM, negara di dunia dikelompkkkan menjadi 3:

1. Kelompok negara low human development, memiliki nilai IPM antara 0 sampai 0.50

2. Kelompok negara medium human development, memiliki nilai IPM antara 0.50 sampai 0.79

3. Kelompok negara high human development, memiliki nilai IPM antara 0.79 sampai 1 
Negara dengan pendapatan perkapita yang tinggi cenderung memiliki nilai IPM yang tinggi pula. Namun fenomena ini tidak terjadi pada semua negara. Misalnya, Iran yang memiliki pendapatan perkapita 1.5 kali lebih besar daripada Thailand memiliki nilai IPM yang lebih tinggi daripada Iran.

\begin{tabular}{|c|c|c|c|c|}
\hline \multicolumn{5}{|c|}{ 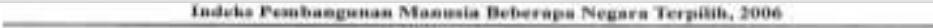 } \\
\hline Negara & 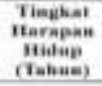 & $\begin{array}{c}\text { Tisuher } \\
\text { Meivk Iferar } \\
\text { (Wh Bewesa) }\end{array}$ & $\begin{array}{c}\text { Gov } \\
\text { Wer Kapira } \\
\text { ifres, lis s? }\end{array}$ & Nilas 6 Wh \\
\hline \multicolumn{5}{|l|}{ Wigh Hawien Bewweyowiver } \\
\hline Nornevie & 70,4 & $\log , 0$ & II. anz & Q.abil $(1)$ \\
\hline Ivane & 62,4 & 40,0 & 31,951 & $0,056(5)$ \\
\hline Aneriba Serika & 78.0 & teg,e & asmoll & $0,910(15)$ \\
\hline Inceris & 70,2 & 4ip.e & 30.821 & $0,9 \mathrm{n} 2(21)$ \\
\hline IElael & ain, s & $\omega, 1$ & 34,405 & $0,030(34)$ \\
\hline Sinengura & $7 m, 9$ & 03,4 & 47,436 & $0,91 \times(2 \mathrm{E})$ \\
\hline \multicolumn{5}{|l|}{ 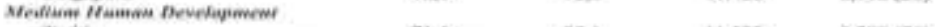 } \\
\hline Turk! & 7,6 & 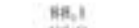 & 11,939 & $0,796(76)$ \\
\hline Maitand & 70,0 & 43.9 & 7,613 & $0,746(2)$ \\
\hline Han & 70,3 & B., 0 & 10031 & $0,777,(124)$ \\
\hline Intknessis & $\Upsilon_{0,1}$ & 91,0 & $x .45$ & $0,726(100)$ \\
\hline Tnolis & 64,1 & $6.5,2$ & 2,450 & $0,6006132 x$ \\
\hline Mambieja & $5 \%, 1$ & 75.6 & 1619 & $0,575(136)$ \\
\hline \multicolumn{5}{|l|}{ 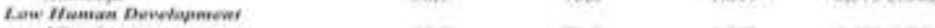 } \\
\hline Neavia & $+6,6$ & 71,0 & $1,8.9$ & $0,404(1,9)$ \\
\hline Trmor L.nate & 60,2 & 50,1 & 668 & $0,4 \mathrm{~s} 3(1 \mathrm{sen})$ \\
\hline rethicois & 52,2 & 35,9 & 700 & $0,789(169)$ \\
\hline Negara Eerpenchasilan Tines! & 70,3 & 90,9 & 35,063 & 0,942 \\
\hline Negaris Berpenghasiles Meneaguh & 71,1 & 01.4 & 6.6 .9 & 0,774 \\
\hline 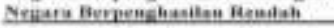 & $+0,3$ & 63. & 1.949 & $0,5 \sin$ \\
\hline
\end{tabular}

Pelajaran yang dapat ditarik dari tabel IPM suatu negara adalah bahwa nilai IPM dipengaruhi oleh kebijakan internal pemerintah negara tersebut terkait aspek pembangunan manusianya, bukan dari tinggi rendahnya pendapatan per kapita. 
Kebijakan pemerintah untuk mendukung aspek pembangunan manusia dapat dilihat dari proporsi anggaran pemerintah untuk membangun sektor pendidikan dan kesehatan. Besarnya proporsi anggaran pemerintah yang dialokasikan untuk kedua sektor tersebut mencerminkan keberpihakan pemerintah terhadap aspek pembangunan manusia.

\section{E. Karakteristik Negara Berkembang}

Suatu negara akan dikatakan sebagai negara berkembang apabila memiliki beberapa karakteristik dari negara berkembang itu sendiri. beberapa karateristik dari negara berkembang antara lain sebagai berikut:

1. Tingkat pertumbuhan penduduk yang tinggi.

Hal yang sangat berbeda yang kita temukan di antara negara maju dan negara berkembang terletak pada beberapa hal, dan salah satunya pada tingkat pertumbuhan penduduk. Pertumbuhan penduduk memang menjadi salah satu ciri yang menunjukkan suatu negara apakah tergolong dalam negara berkembag ataukah negara maju. Di negara maju, kita akan menemukan tingkat pertumbuhan penduduk yang 
rendah, bahkan sangat rendah. Hal ini dipengaruhi dan didukung oleh berbagai macam hal, seperti gaya hidup yang serba modern hingga sifat hedonis dan individualistis yang tinggi. namun hal- hal tersebut tidak akan kita temukan di negara berkembang. negara berkembang memiliki sebagian penduduk yang masih mengenyam pendidikan rendah. Selain itu masyarakat negara berkembang masih sangat kental dengan adat istiadat serta kebudayaan. Hal ini tentu saja akan menimbulkan ikatan yang kuat diantara sesama anggota keluarga. Dengan demikian mempunyai keturunan yang banyak menjadi suatu anugerah tersendiri.

Dengan perbedaan tingkat pendidikan dan kebudayaan serta pola pikir yang masih tradisional, maka menjadikan tingkat pertumbuhan di negara berkembang cenderung tinggi. Tingkat pertumbuhan penduduk yang tinggi akan menyebabkan banyak permasalahan timbul, terutama di masa depan. Beberapa permasalahan yang dapat timbul yang diakibatkan oleh hal ini adalah mahalnya biaya pendidikan, sulitnya tanah untuk membangun rumah, dan lain sabagainya. Selain itu 
pertumbuhan penduduk yang tinggi juga akan menaikkan anggaran pengeluaran negara.

2. Mempunyai tingkat pengangguran yang tinggi.

Negara berkembang merupakan negara yang mempunyai beberapa tanda khusus yang dapat kita lihat. Beberapa tanda atau ciri atau karakteristik dari negara berkembang ini memiliki sifat serba tinggi. selain tingginya pertumbuhan penduduk, ternyata negara berkembang juga bisa ditandai dengan tingginya tingkat pengangguran. Seperti yang kita ketahui bersama bahwa pengangguran merupakan momok yang dijauhi oleh negara- negara di dunia ini (baca: negara penghasil kopi terbesar di dunia). bagaimanapun juga yang namanya pengangguran itu tidak produktif dan banyak mendatangkan permasalahan, baik permasalahan di bidang ekonomi, sosial masyarakat, hingga kriminalitas. Pengangguran sendiri merupakan seseorang yang tidak mempunyai pekerjaan atau yang bekerja namun hanya beberapa jam saja seminggu. Orang dikatakan sebagai pengangguran apabila memenuhi beberapa syarat, antara lain sebagai berikut:

a. Sedang mencari pekerjaan 
b. Sudah memiliki pekerjaan namu belum mulai bekerja

c. Tidak memiliki pekerjaan karena merasa tidak akan mendapatkan

d. Sedang mempersiapkan usaha

Keberadaan pengangguran di tengah- tengah masyarakat memang menjadi suatu masalah. Sebab pengangguran tidak mendapatkan pemasukkan, namun tetap mengeluarkan uang untuk bertahan hidup. Otomatis hal ini akan menjadi tanggungan bagi negara secara tidak langsung. Dan selain hal itu, pengangguran akan menimbulkan berbagai macam dampak baik dampak dalam bidang perekonomian maupun dalam bidang sosial. Beberapa dampak yang bisa ditimbulkan dari status pengangguran antara lain dapat menyebabkan tingginya pengeluaran negara hingga menimbulkan kriminalitas dimana- mana.

3. Ketergantungan pada sektor pertanian atau primer

Perekonomian adalah salah satu bagian yang yang paling penting bagi suatu negara. Perekonomian suatu negara menjadi salah satu cerminan kesejahteraan 
masyarakat. Banyak cara yang bisa dilakukan suatu negara untuk menopang perekonomiannya. Sektor- sektor perekonomian ini bisa bermacam- macam, seperti sektor ekstraktif, industri, perdagangan dan juga jasa. bagi negara maju, sektor yang mayoritas digeluti dan menjadi andalan negaranya adalah sektor industri. Sektor industri sangat dibutuhkan oleh banyak orang dan menjadi sektor yang memproduksi banyak benda- benda yang dibutuhkan manusia sehari- hari.

Namun tidak seperti negara maju, di negara berkembang sektor yang sangat dijadikan penopang adalah sektor primer, dalam hal ini adalah sktor pertanian. Selain sektor pertanian, bisa juga sektor ekstraktif atau mengambil langsung dari alam seperti pertambangan, perkebunan, perikanan dan lain sebagainya. Di negara berkembang memang masih banyak dijumpai lahan- lahan pertanian, lahan perkebunan dan lainnya, maka dari itulah banyak masyarakat yang bekerja disana. Selain karena luasnya lahan, salah satu faktor yang mendukung adalah kurangnya tingkat pendidikan masyarakatnya sehingga banyak masyarakat yang bekerja dengan kekuatan tangannya, seperti halnya sektor primer. 
4. Pasar dan informasi tidak sempurna

Di negara berkembang banyak hal yang masih jauh dari kata kesempurnaan. Beberapa diantaranya adalah pasar serta iniformasi. Keterbatasan teknologi serta kelangkaan sumber daya manusia yang berkualitas menjadikan negara berkembang memiliki sistem informasi yang kurang sempurna dan pastinya tertinggal jauh dengan negara maju. Sistem komunikasi di negara maju sudah banyak menggunakan peralatan yang super canggih dan belum ada di negara berkembang. Karena di negara maju sudah sangat berkembang, maka tidak heran apabila di negara berkembang tertinggal. Hal ini karena masyarakat negara maju mempunyai cukup uang untuk membali peralatan komunikasi yang canggih didukung dengan kebutuhan mereka yang penuh dengan mobilitas. Bahkan tidak hanya pada peralatan komunikasi saja, namun juga dalam hal pasar di negara berkembang juga belum tertata rapi. Banyak hal yang menjadi masalah di negara berkembang sehingga menyebabkan pasar tidak bertumbuh dengan lancar.

5. Pendapatan perkapita rendah 
Salah satu ciri yang cukup mencolok dalam menandai negara berkembang adalah pendapatan perkapita penduduknya yang masih rendah. Negara berkembang sangat identik dengan keterbatasan dan keterbelakangan. Dengan pendapatan perkapita yang rendah, maka akan banyak penduduk negara berkembang hidup dalam batas garis kemiskinan. Hal ini akan membuat kesejahteraan penduduk menjadi sangat jauh dari kata baik. Dengan pendapatan perkapitan yang hanya sedikit itu, kebanyakan masyarakat hanya bisa memenuhi kebutuhan pokok saja, dan sedikit kemungkinan untuk mereka bisa memenuhi kebutuhan sekunder, atau bahkan kebutuhan mewah. Karena jumlah pendapatan yang pas- pasan, maka penduduk negara berkembang ini hanya akan memperoleh makanan yang sederhana saja. Bisa jadi masyarakat negara berkembang akan kekurangan gizi. Selain itu, rumah- rumah penduduk di negara berkembang banyak yang masih sangat sederhana. Di beberapa negara berkembang bahkan masih ada anak- anak serta bayi- bayi yang terlantar, kurang gizi sehingga sangat mudah untuk terserang penyakit. Perolehan pendidikan juga dalam batas yang biasa saja, disesuaikan dengan pendapatan 
yang diperoleh mereka. Tidak heran, di negara berkembang jumlah siswa yang berprestasi akan sangat jauh beda dengan negara maju yang telah memiliki fasilitas pendidikan yang lebih lengkap.

6. Kesempatan kerja yang kurang memadai

Kesempatan kerja yang kurang memadai menjadi salah satu ciri negara berkembang. kesempatan kerja yang sangat terbatas ini dikarenakan oleh berbagai macam faktor. Salah satu hal yang membuat kesempatan kerja ini menjadi tidak luas adalah karena perekonomian di negara berkembang hanya mengandalkan sektor pertanian. Dengan demikian lapangan kerja yang dibuka juga tidak banyak. Kesempatan kerja yang terbatas tersebut akan melahirkan banyak pengangguran yang akan berdampak buruk bagi negara. Selain adanya kesempatan kerja yang terbatas, ciri lain dari negara berkembang adalah kurangnya atau sedikitnya jumlah wirausaha. Sedikitnya jumlah wirausaha ini dikarenakan kurangnya pengetahuan masyarakat tentang membangun bisnis serta terbatasnya modal yang dipunyai masyarakat, ditambah dengan berbagai macam pendapat yang keluar 
dari pemikiran yang masih kolot diantara masyarakat desa.

7. Adanya keterbatasan modal usaha

Telah dikatakan sebelumnya bahwa salah satu ciri dari negara berkembang adalah sedikitnya jumlah pengusaha atau wirausaha. Hal ini terjadi karena dua hal yakni kurangnya pengetahuan untuk berwirausaha serta terbatasnya jumlah modal yang dimiliki. Jumlah modal terbatas karena negara berkembang hanya mengandalkan sektor primer saja, sehingga pendapatan yang diterima pun juga hanya cukup untuk membiayai kehidupan seharihari, dan sangat sedikit atau bahkan tidak ada sama sekali yang ditabung. Maka dari itulah masyarakatnya yang tinggal di negara berkembang hanya mempunyai sedikit modal yang dapat digunakan untuk membangun usaha. Merintis usaha pun tidak selalu langsung berhasil, terkadang kita mengalami kerugian terlebih dahulu. Ketika percobaan pertama rugi, maka kita akan mencoba kembali. Kali kedua membangun usaha itulah kita membutuhkan modal lagi, maka dari itu modal yang disediakan harus memenuhi jumlah yang cukup. 
Karakteristik yang telah disebutkan tersebut mungin tidak semua dimiliki oleh suatu negara berkembang, namun poinpoin yang telah disebutkan di atas merupakan karakteristik negara berkembang secara umum dan paling banyak ditemui.

\section{F. Pendapatan Nasional}

Secara umum pendapatan nasional merupakan seluruh pendapatan yang diterima oleh seluruh anggota masyarakat atau seluruh rumah tangga keluarga dalam suatu negara dalam pada kurun waktu tertentu, dimana biasanya satu tahun. Pendapatan nasional juga bisa diartikan sebagai hasil produksi nasional yang merupakan hasil produksi yang dihasilkan oleh anggota masyarakat dalam suatu negara dalam kurun waktu satu tahun.

Pendapatan nasional bisa dihitung menggunakan tiga pendekatan yaitu:

1. Pendekatan Produksi

Merupakan metode penghitungan menggunakan nilai tambah produk atau nilai produk jadi. Pendekatan ini bertujuan agar tidak terjadi 
perhitungan yang ganda sebab adanya produksi yang bertingkat. Hal itu disebabkan suatu produksi digunakan sebagai bahan baku produksi produk lain. Pendapatan nasional yang menggunakan pendekatan produksi bisa dihitung menggunakan rumus:

$$
\mathrm{Y}: \Sigma=\mathrm{Pn} \cdot \mathrm{Qn}
$$

Dimana,

$\mathrm{Y}=$ Pendapatan Nasional

$\mathrm{Pn}=$ Harga jual produk jadi

Qn= Jumlah produksi produk asli

2. Pendekatan Pengeluaran

Pendapatan pengeluaran adalah metode penghitungan yang menggunakan seluruh pengeluaran pelaku kegiatan ekonomi di suatu negara. Adapun pengeluaran yang dihitung terdiri atas konsumsi rumah tangga, investasi perusahaan, pengeluran pemerintah serta ekspor dan impor dengan masyarakat luar negeri. 
Penghitungan pendapatan nasional yang menggunakan pendekatan ini bisa dihitung dengan rumus:

$$
Y: \Sigma=C+I+G+(X-M)
$$

Dimana,

$\mathrm{Y}=$ Pendapatan Nasional

$\mathrm{C}=$ Konsumsi rumah tangga

I = Investasi perusahaan

$\mathrm{G}=$ Pengeluaran Pemerintah

$X=$ Jumlah ekspor

$\mathrm{M}=$ Jumlah impor

3. Pendekatan Pendapatan

Merupakan metode penghitungan yang menggunakan jumlah seluruh pendapatan yang diterima rumah tangga konsumsi suatu negara. Adapun pendapatan yang dihitung meliputi pendapatan faktor produksi yaitu upah, sewa, bunga, dan laba. Selain itu juga ada pendapatan non-faktor produksi. 


Penghitungan pendapatan nasional yang
menggunakan pendekatan ini bisa dihitung
menggunakan rumus:

$$
Y: \Sigma=w+r+i+\pi
$$

Dimana,

$$
\begin{aligned}
& Y=\text { Pendapatan nasional } \\
& \mathrm{W}=\text { upah } \\
& \mathrm{r}=\text { sewa } \\
& \mathrm{i}=\text { bunga } \\
& \pi=\text { laba }
\end{aligned}
$$

Besar kecilnya pendapatan nasional dipengaruhi oleh beberapa faktor yaitu:

a. Permintaan Dan Penawaran Agregat

Dimana agregat menunjukkan hubungan antara seluruh jumlah permintaan terhadap barang maupun jasa sesuai dengan tingkat harga. Permintaan agregat sendiri merupakan suatu daftar dari seluruh barang dan jasa yang akan dibeli oleh sektor ekonomi pada berbagai tingkat harga. Sementara itu penawaran agregat merupakan hubungan antara seluruh penawaran barang dan jasa 
yang ditawarkan oleh perusahaan-perusahaan dengan tingkat harga tertentu.

b. Investasi

Dimana pengeluaran untuk investasi oleh perusahaan atau yang lainnya merupakan salah satu komponen penting dari pengeluaran agregat. Pelaku faktor produksi yang mampu berinvestasi banyak menunjukkan bahwa mereka mengalami kemajuan atau peningkatan pendapatan. Hal itu kemudian juga mempengaruhi pendapatan nasional suatu negara.

c. Konsumsi Dan Tabungan

Dimana konsumsi merupakan pengeluaran secara keseluruhan untuk memperoleh barang dan jasa dalam aktifitas perekonomian dalam jangka waktu tertentu. Sedangkan, tabungan merupakan bagian dari pendapatan yang tidak dikeluarkan untuk berbagai konsumsi.

Bisa dikatakan bahwa semakin banyak tabungan artinya pendapatan nasional menjadi lebih banyak atau meningkat. Begitu pula dengan tingkat konsumsi yang 
meningkat menunjukkan bahwa pendapatan suatu masyarakat maupun negara juga baik dan meningkat.

\section{G. Soal Soal}

1. Jelaskan definisi dari Ekonomi Pembangunan!

2. Jelaskan indikator moneter!

3. Jelaskan indikator non moneter!

4. Jelaskan indikator campuran!

5. Sebutkan ciri dari negara berkembang! 

dan Pembangunan Ekonomi

\section{A. Pengelompokan Teori}

Delman (1961) mengidentifikasi terdapat 3 faktor utama yang mendorong terjadinya perubahan teori dan paradigma pembangunan ekonomi dari masa ke masa.

1. Perubahan ideologi. Setiap generasi pemikir ekonomi mempunyai basis ideologinya masing masing sehingga memiliki rujukan teoritis dan rekomendasi kebijakan yang berlainan. Bila terjadi perubahan ideologi, kerangka dan rekomendasi kebijakan juga ikut berubah.

2. Revolusi dan inovasi teknologi. Terjadi perubahan yang fundamental dari aktifitas ekonomi masa kini karena dampak dari revolusi dan inovasi teknologi. Lahirnya paradigma perekenomian berbasis pengetahuan adalah produk dari revolusi tersebut.

3. Perubahan lingkungan internasional sebagai dampak globalisasi ekonomi. Hal ini tercermin pada semakin 
terintegrasinya kegiatan ekonomi antar bangsa, yang mengarah pada borderless economy. Indikasinya adalah: (1) liberalisasi ekonomi dan intensifikasi perdagangan bebas antar negara, (2) meluasnya operasi perusahaan multinasional, dan (3) pesatnya perkembangan bisnis keuangan internasional.

Lincolin Arsyad (2001) mengelompokkan beberapa mazhab teori dalam pertumbuhan dan pembangunan ekonomi. Beberapa mazhab yang dibahas adalah mazhab historismus, klasik, Keynesian, neoklasik, teori pertumbuhan endogen, teori Schumpeter, dan teori ketergantungan.

Di dunia, sangat banyak sekali mazhab ekonomi selain yang telah disebutkan diatas. Mengingat buku ini hanya sebagai pengantar, maka yang dibahas adalah mazhab teori yang dianggap cukup representatif.

\section{B. Mahzab Historismus}

Mazhab historismus dikenal sebagai penganjur paham nasionalisme, baik dalam kehidupan ekonomi maupun bermasyarakat. Mazhab ini lahir di Jerman, dimana nilai nasionalisme tertanam begitu kuat pada masyarakatnya. Pada abad ke 19, adanya perbedaan institusi sosial dan ekonomi 
antara Jerman dan Inggris berimplikasi pada perbedaan ideologi ekonomi mereka. Teori ekonomi klasik yang berasal dari Inggris dianggap tidak mampu memberikan solusi atas situasi di Jerman pada saat itu. Karena itu, mazhab Historismus berkembang sebagai sebuah kritik atas doktrin ekonomi klasik.

Menurut mazhab Historismus, fenomena ekonomi dianggap sebagai sebuah "bagian" tertentu dari perjalanan sebuah bangsa. Oleh karena itu, pemikiran dan penelitian ekonomi harus berada dalam perspektif sejarah sehingga kebijakan yang dihasilkan di dasarkan atas realitas dunia nyata, bukan berdasarkan pemikiran abstrak dan dengan asumsi yang terkadang kurang realistis.

Terdapat empat prinsip dan ajaran utama dari mazhab Historismus.

1. Menekankan pada pendekatan yang bersifat evolusioner pada ilmu ekonomi. Mazhab ini memusatkan perhatiannya pada pertumbuhan dan pembangunan secara kumulatif. Menurut mazhab ini, sebuah masyarakat akan senantiasa berubah, namun dengan siklus yang konstan. 
2. Menekankan pada pentingnya peranan pemerintah dalam perekenomian. Mazhab ini menekankan tentang adanya "komunalisme ekonomi" dimana organisme sosial dipandang sebagai akumulasi dari setiap unit yang ada di dalamnya dan membentuk sebuah kesatuan yang unik, bukan sebagai unit yang terpisah dan berjalan sendiri (individualis). Mazhab ini juga menekankan tentang campur tangan pemerintah dalam perekenomian dan tidak mempercayai invisible hand yang mampu menghasilkan keseimbangan pasar.

3. Mazhab Historimus menggunakan pendekaran induktif dalam analisisnya dan mempelajari ekonomi dari perspektif sejarah sejarah umat manusia.

4. Mazhab Historismus mendukung pandangan yang bersifat konservatif. Mazhab ini memandang perlu adanya kebijakan yang mengarah pada perbaikan kondisi masyarakat secara umum karena terdapat dampak positif yang akan dihasilkan

Friedrich List dipandang sebagai pelopor pemikiran ekonomi Mahzab Historismus. Menurut List, perkembangan 
ekonomi hanya terjadi jika dalam masyarakat ada kebebasan, baik dalam berpolitik maupun ekonomi dalam kehidupan berbangsa sehari hari. List juga menegaskan bahwa negara harus melindungi kepentingan golongan lemah dalam masyarakat.

List berbependapat bahwa terdapat 5 tahap perkembangan ekonomi didasarkan cara produksi:

a. Tahap berburu, merupakan ciri masyarakat primitive dimana memenuhi kebutuhannya hanya dari alam.

b. Tahap beternak, tahap ini kegiatan beternak sudah dilakukan, tetapi masyarakat bersifat nomaden.

c. Tahap agraris, masyarakat mulai menetap dan bertani secara subsisten.

d. Kombinasi antara tahap bertani, industri manufaktur, dan perdagangan yang polanya masih sederhana.

e. Kombinasi antara tahap bertani, industri manufaktur, dan perdagangan yang sudah maju. 
Menurut List, sistem perdagangan bebas sebagaimana dianjurkan oleh kaum Klasik hanya cocok diterapkan pada negara yang telah berada pada tahap pengembangan ke lima. Perdagangan bebas tidak cocok digunakan pada negara yang industrinya masih belum berkembang. Solusinya adalah List menekankan perlunya proteksi bagi industri lokal agara memiliki daya saing di tingkat global. List juga menyatakan bahwa proteksi hanya bersifat sementara saja, setelah industri mulai berkembang dan mapan maka proteksi harus dihentikan.

Untuk mengejar ketertinggalan NSB dalam pembangunan, Intervensi yang dilakukan negara bukan hanya terbatas pada bidang ekonomi tetapi juga diperlukan pada bidang bidang lain seperti sosial, politik, dan hukum. Tanpa adanya intervensi yang efektif pada bidang tersebut, pembangunan ekonomi tidak akan berjalan dengan mulus.

\section{Mahzab Klasik}

Uraian Pekerjaan / Deskripsi Jabatan / Job Description adalah paparan yang mencakup pekerjaan dasar dari suatu jabatan yang termasuk tugas, wewenang, tanggung jawab dan informasi-informasi penting lainnya yang melekat pada 
jabatan tersebut. Contoh Informasi-informasi dalam deskripsi jabatan tersebut diantaranya seperti nama Jabatan, lokasi dan lingkungan pekerjaan, informasi pelaporan, ringkasan pekerjaan, sifat dan tujuan pekerjaan, tugas-tugas yang harus dilakukan, kondisi kerja, mesin dan peralatan yang bisa digunakan dalam penyelesaian kerja, serta bahaya dan risiko yang terlibat didalam pekerjaan tersebut.

Para ekonom pada Mazhab Klasik memiliki persepsi ekonomi yang berkebalikan dari Mahzab Historismus dalam tatanan ekonomi masyarakat, yaitu:

a. Kebijakan pasar bebas (laizez faire), yaitu setiap individu maupun unit usaha harus diberikan kebebasan dalam kegiatan ekonominya.

b. Kegiatan ekonomi yang dilakukan atas dasar mekanisme pasar akan jauh lebih bermanfaat daripada jika ada campur tangan pemerintah di dalamnya. Peran pemerintah hanya dibatasi pada bidang hukum, pertahanan, pendidikan, dan penyediaan jasa publik lain.

c. Nilai dan harga barang, tingkat upah, tingkat sewa tanah, dan tingkat laba ditentukan oleh 
mekanisme tarik menarik antara permintaan dan penawaran di pasar.

Adam Smith dijuluki sebagai bapak IImu Ekonomi sekaligus pencipta Mazhab Klasik. Adam Smith merupakan penulis dari buku fenomenal, An Inquiry into the Nature and Causes of the Wealth of Nations, yang menyatakan bahwa kegiatan ekonomi yang didasarkan pada mekanisme pasar dinilai akan mampu mengalokasikan setiap sumbernya secara efisien. Smith menyatakan bahwa terdapat tangan gaib (invisible hand) yang bekerja mengalokasikan setiap sumber daya agar perekenomian tetap berada pada keseimbangan.

Di dalam bukunya, Smith menentang pandangan kaum merkantilis mengenai pentingnya persediaan emas dan perak dalam jumlah besar bagi perekenomian. la juga menentang padangan kaum fisiokrat mengenai peran sentral tanah sebagai sumber utama dari nilai. Sebaliknya, Smith menekankan tentang makna tenaga kerja dalam perekenomian. Smith berargumen bahwa peningkatan produksi dapat dicapai lewat pembagian kerja yang baik.

Inti dari proses pertumbuhan ekonomi menurut Smith membutuhkan dua aspek utama dalam yang harus dipenuhi, 
yaitu (1) pertumbuhan output total dan (2) pertumbuhan penduduk.

1) Pertumbuhan output total.

Menurut Smith, unsur dari sistem produksi suatu negara adalah:

- Sumber daya alam yang tersedia, yang dicerminkan dari ketersediaan tanah. Pertumbuhan output akan terhenti jika sumber daya alam telah digunakan secara optimal.

- Sumber daya manusia, yang direpresentasikan dari jumlah penduduk. Spesialisasi merupakan salah satu faktor kunci bagi peningkatan produktifitas tenaga kerja. Spesialisasi akan melahirkan kemahiran, efisiensi, dan merangsang penemuan teknologi baru yang meningkatkan produktifitas.

- Akumulasi modal yang dimiliki. Menurut Smith, stok modal memegang peranan paling penting dalam pembangunan ekonomi. Ketersediaan stok modal ditentukan oleh jumlah tabungan masyarakat. Smith memandang bahwa hanya 
para tuan tanah dan pengusaha yang memiliki kemampuan untuk menabung, karena mereka adalah kaum "pemilik modal".

2) Pertumbuhan penduduk.

Menurut Smith, pertumbuhan penduduk dinilai mampu mendorong pertumbuhan ekonomi. Bertambahnya penduduk akan memperluas pasar, dan perluasan pasar akan meninggikan tingkat spesialisasi dalam perekenomian. Adanya spesialisasi akan mengarah pada peningkatan produktifitas tenaga kerja dan mendorong perkembangan teknologi.

Menurut Smith, jumlah penduduk akan meningkat jika tingkat upah yang berlaku lebih tinggi dari tingkat upah subsisten (tingkat upah yang hanya cukup untuk sekedar bertahan hidup). Tingkat upah yang berlaku, menurut smith, ditentukan oleh tarik menarik antara kekuatan permintaan dan penawaran tenaga kerja.

\section{Mahzab Keynesian}

Teori Keynes, yang telah dilengkapi dan dikembangkan oleh Roy Harrod (1939, An essay of Dynamic Teory) dan Evsey Domar (1947, Expansion \& Employment), menganalisis syarat 
syarat yang diperlukan agar suatu perekenomian dapat tumbuh dan berkembang dalam jangka panjang. Teori Keynes yang sudah disempurnakan lebih sering disebut Teori Harrod - Domar yang menciptakan pondasi bagi Mahzab Keynesian.

Menurut Teori Harrod - Domar, pembentukan modal merupakan faktor penting yang menentukan pertumbuhan ekonomi. Pembentukan modal didapat dari proses akumulasi tabungan. Teori ini meyakini bahwa jika pada suatu periode tertentu dilakukan sejumlah pembentukan modal, maka pada masa berikutnya perekenomian tersebut akan memiliki kemampuan yang lebih tinggi dalam menghasilkan barang dan jasa.

Teori Harrod - Domar memiliki beberapa asumsi:

a. Perekonomian dalam keadaan penuh dan faktor produksi yang ada juga dimanfaatkan secara penuh.

b. Perekonomian terdiri dari dua sektor: sektor rumah tangga dan sektor perusahaan.

c. Besarnya tabungan masyarakat proporsional dengan besarnya pendapatan nasional. 
d. Kecendrungan menabung (marginal propensity to save = MPS) besarnya tetap, demikian juga rasio antara modal - output (capital - output ratio $=$ COR) dan rasion pertambahan modal output (incremental capital - output ratio $=$ ICOR)

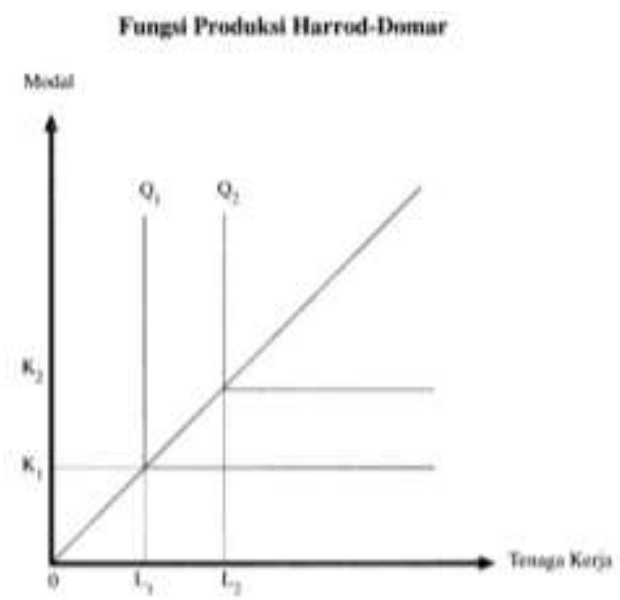

Gambar 2.1

Fungsi produksi Harrod Domar

\section{E. Teori Pertumbuhan Neo Klasik}

Teori pertumbuhan ekonomi Neoklasik berkembang pada tahun 1950an. Teori ini mengacu pada kerangka analisis yang dikembangkan Robert Solow dan Trevor Swan. Menurut Solow \& Swan, pertumbuhan ekonomi tergantung pada 
ketersediaan faktor produksi (penduduk, tenaga kerja, akumulasi modal) dan tingkat kemajuan teknologi.

Pandangan dari teori Solow \& Swan didasarkan pada anggapan yang mendasari analisis ekonomi klasik yaitu bahwa perekenomian berada pada tingkat pengerjaan penuh (full employment) dan tingkat pemanfaatan penuh (full utilization) dari faktor produksi. Dengan kata lain, perekenomian akan terus berkembang dan semuanya bergantung pada pertambahan penduduk, akumulasi capital, dan kemajuan teknologi.

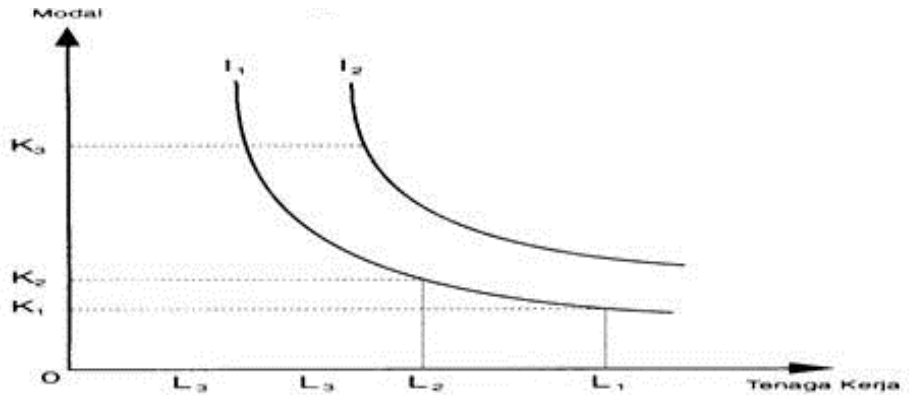

Gambar 2.2

Fungsi Produksi Neo Klasik

Gambar 2.2 menunjukan sifat teori pertumbuhan neoklasik. Fungsi produksi ditunjukan oleh I1 dan 12. dalam fungsi produksi I1 yang diciptakan dengan menggunakan 
modal dan tenaga kerja, misal dibutuhkan: (A) K3 dengan L3, (B) K2 dengan L2, dan (C) K1 dengan L1.

Tetapi output tetap dapat mengalami perubahan meski modalnya konstan. Output dapat diperbesar dari I 1 menjadi 12 dengan tenaga kerja yang digunakan bertambah dari L3 menjadi L4 meski modal yang digunakan tetap di titik K3.

Dalam teori pertumbuhan neoklasik juga mengenal adanya konsep diminishing marginal productivity.

\section{F. Teori Pertumbuhan Endogen}

Melalui tulisannya yang berjudul Endogenous Technological Change dan The Origins of Endogenous Growth di tahun 1994, Michael Romer menggagas terbentuknya Teori Pertumbuhan Endogen.

Umumnya, teori pertumbuhan ekonomi hanya menekankan pentingnya akumulasi modal dalam pertumbuhan ekonomi. Artinya, untuk memiliki laju pertumbuhan ekonomi yang tinggi, suatu negara membutuhkan investasi yang tinggi pula. Dana untuk membiayai investasi berasal dari tabungan, dan kunci utama 
pertumbuhan ekonomi terletak dari kemampuan suatu negara dalam mengakumulasikan tabungan.

Sementara model pertumbuhan endogen menyajikan kerangka teoritis yang lebih luas dalam menganalisis proses pertumbuhan ekonomi. Teori ini mengidentifikasi bahwa faktor yang mempengaruhi pertumbuhan ekonomi berasal dari dalam (endogenous), modal memiliki arti yang lebih luas dengan mencakup modal insani (human capital).

Secara struktural, teori pertumbuhan endogen hampir mirip dengan teori neoklasik, tetapi berbeda asumsi dari kesimpulan yang diambil. Teori neoklasik menggunakan asumsi diminishing marginal returns sementara teori pertumbuhan endogen menggunakan asumsi increasing returns to scale pada fungsi agregatnya.

Menurutt Romer, asumsi increasing returns to scale pada capital investment lebih realistis digunakan karena adanya mekanisme learning by doing pada sumber daya manusia. Dengan adanya investasi dan spesialisasi pada bidang SDM dan ilmu pengetahuan, manusia akan dapat menciptakan metode baru dalam berproduksi sehingga diperoleh keuntungan ekonomis tertentu. 
Dalam model Endogen, faktor teknologi memegang peranan penting, namun bukan berarti menjadi hal yang menentukan dalam pertumbuhan jangka panjang. Romer menekankan bahwa unsur ilmu pengetahuan dan modal insani juga memiliki peran yang vital bagi pembangunan jangka panjang.

\section{G. Teori Schumpeter}

Selanjutnya, dikatakan bahwa sasaran perencanaan tenaga kerja adalah untuk memastikan bahwa organisasi :

a) Mendapatkan dan mempertahankan kuantitas dan kualitas tenaga kerja yang diperlukan.

b) Mampu mengantisipasi masalah-masalah yang muncul dari potensi kelebihan atau kekurangan tenaga kerja.

Schumpeter boleh dikatakan sebagai orang pertama yang mendalami teori pertumbuhan ekonomi melalui bukunya The Theory of Economic Development tahun 1911 dan Business Cycle tahun 1939.

Salah satu pendapat Schumpeter yang melandasi teori pembangunannya adalah keyakinan bahwa kapitalisme merupakan sistem yang paling baik untuk menciptakan 
pembangunan ekonomi yang pesat. Menurut Schumpeter, faktor utama yang menyebabkan perkembangan ekonomi adalah proses inovasi dan pelakunya adalah para innovator atau pengusaha. Jadi kemajuan ekonomi hanya dapat dicapai dengan adanya inovasi oleh para entrepreneur.

Dikatakan oleh Schumpeter, pembangunan ekonomi akan berkembangan pesat dalam lingkungan masyarakat yang menghargai dan merangsang setiap orang untuk menciptakan hal yang baru, dan lingkungan tersebut adalah masyarakat yang mendukung dan menganut asas laissez faire, serta bukan dalam masyarakat sosialis atau komunis yang cenderung mematikan kreatifitas penduduknya.

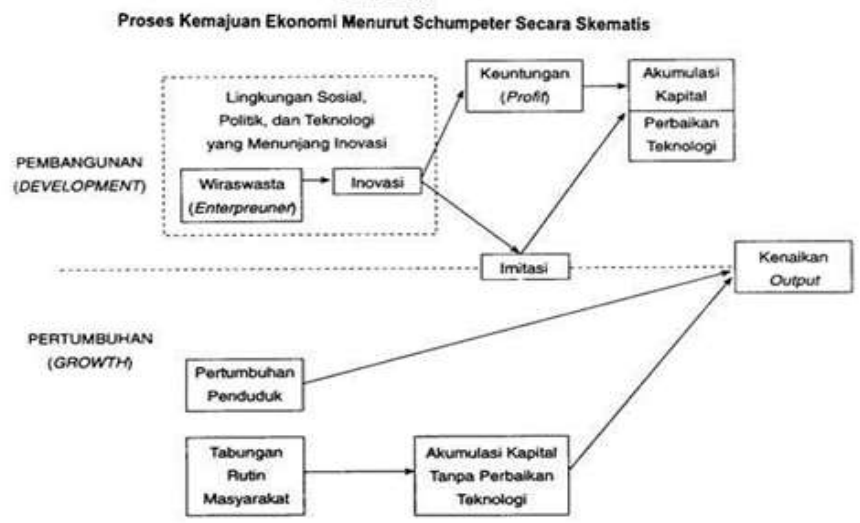

Gambar 2.3

Skema Pertumbuhan Ekonomi Schumpeter 
Pembangunan ekonomi berawal dari suatu lingkungan sosial, politik, dan teknologi yang menunjang kreatifitas pengusaha. Adanya lingkungan tersebut akan melahirkan pengusaha perintis (pioneer) yang menerapkan ide baru dalam kehidupan ekonomi. Mungkin tidak semua pioneer akan berhasil, tetapi jika sukses ia akan mendapat keuntungan monopoli dalam inovasinya tersebut.

\section{H. Teori Ketergantungan}

Dependencia theory pertama kali dikembangkan di Amerika Latin pada tahun 1960an oleh Paul Baran. Menurut teori ini, fenomena keterbelakangan NSB terjadi saat masyarakat ekonomi negara NSB / prakapitalis tergabung ke dalam sistem ekonomi dunia yang kapitalistik sehingga mereka terperangkap ketergantungan dan dominasi negara maju (core). Akibatnya, negara tersebut kehilangan otonominya dan berakhir menjadi negara pinggiran (periphery).

Pendekatan dependensia yang amat populer di Amerika Latin mulai umum digunakan diseluruh dunia seiring diterbitkannya literatur tentang kisah "bandit ekonomi" yang secara sengaja merusak tatanan ekonomi NSB. 
Salah satu tokoh menonjol dalam teori ini adalah Andre Gunner Frank, melalui salah satu tulisannya berjudul Capitalism and Underdevelopment in Latin America (1969), bahwa keterbelakangan di negara periphery disebabkan oleh kontak dengan negara core yang menyebabkan negara peripehery terjebak dan terperangkap dalam sistem kapitalisme.

Untuk melengkapi pandangan terhadap proses keterbelakangan negara Amerika Latin, A.G. Frank menyatakan 4 hipotesis:

a. Dalam struktur hubungannya, negara core akan berkembang pesat sedangkan negara periphery akan semakin terpuruk.

b. Negara miskin akan menjadi "satelit" negara maju,

c. Sebagian besar negara pada masa sekarag yang dikelompokkan sebagai negara terbelakang adalah negara yang pada masa lampau memiliki hubungan erat dengan sistem kapitalisme dunia.

d. Semakin maraknya latifundia di negara tersebut. 
Sementara pakar teori ketergantungan lain, Theotonio Dos Santos (1970) mengklasifikasikan ketergantungan dalam 3 jenis:
a. Ketergantungan Kolonial
b. Ketergantungan Industri Keuangan
c. Ketergantungan Teknologi Industri.

\section{Soal Soal}

1. Mengapa Mazhab Historismus lebih menekankan nasionalisme?

2. Jelaskan menurut pendapat Anda, apa definisi dari Laissez Faire!

3. Apa perbedaan mendasar dari Teori Pertumbuhan Keynesian dan Teori Pertumbuhan Endogen?

4. Jelaskan mengapa proses inovasi menjadi hal yang vital dalam Teori Ekonomi Schumpeter!

5. Menurut pendapat Anda, apakah Indonesia termasuk negara yang terjebak pada kapitalisme asing seperti yang dijelaskan pada Teori Ketergantungan? Jelaskan! 


\section{Strategi Pertumbuhan dan Pembangunan Ekonomi}

\section{A. Lingkaran Kemiskinan}

Konsep lingkaran kemiskinan pertama kali dikenalkan oleh Ragnar Nurkse dalam bukunya yang berjudul Problems of Capital Formation in Underdeveloped Countries (1953). Lingkaran kemiskinan dapat didefinisikan sebagai suatu rangkaian kekuatan yang saling mempengaruhi satu sama lain sehingga menimbulkan suatu kondisi dimana sebuah negara akan tetap miskin dan akan mengalami banyak kesulitan untuk mencapai tingkat pembangunan yang lebih tinggi.

Menurut pandangan Nurkse, ada dua jenis lingkaran kemiskinan yang menghalangi NSB untuk mencapai tingkat pembangunan yang pesat, yaitu:

1. Dari segi penawaran modal: disebabkan oleh tingkat pendapatan yang rendah, yang diakibatkan oleh tingkat produktivitas yang rendah, sehingga menyebabkan kemampuan menabung masyarakat juga rendah. 
2. Dari segi permintaan modal: disebabkan oleh investasi yang rendah, karena luas pasar untuk berbagai jenis barangnya terbatas. Terbatasnya jenis barang dalam pasar disebabkan oleh pendapatan masyarakat yang rendah.

Pada bagian lain dari analisisnya, Nurkse menyatakan bahwa peningkatan pasar modal bukan hanya dibatasi lingkaran kemiskinan, tetapi juga oleh adanya international demonstration effect. Efek ini membuat NSB cenderung meniru pola konsumsi dari masyarakat yang lebih maju, sehingga mengarah ke gaya hidup konsumtif yang justru mendorong sebuah negara semakin dalam ke lingkaran kemiskinan.

Lingkaran kemiskinan timbul dari hubungan saling mempengaruhi dari kondisi masyarakat yang masih terbelakang dan kekayaan alam yang belum dimanfaatkan sepenuhnya.

Pada NSB, kekayaan alam bukanlah sepenuhnya diusahakan dan dikembangkan karena tiga alasan, yaitu:

1. Tingkat pendidikan masyarakat yang relatif rendah

2. Kurangnya tenaga ahli yang diperlukan 
3. Terbatasnya mobilitas dari sumberdaya yang ada

\section{B. Teori Kausasi Kumulatif}

Myrdal (1957) menjelaskan sebuah konsep yang sekarang kita kenal sebagai proses kausasi kumulatif. Melalui teori kausasi kumulatif, Myrdal menjelaskan sebab sebab bertambah lebarnya "jurang pembangunan" antara NSB dan negara maju.

Teori Klasik mengatakan bahwa dalam jangka panjang mekanisme pasar akan menciptakan pembangunan yang seimbang antar negara. Myrdal tidak sependapat, ia menyatakan bahwa pembangunan di negara maju akan menyebabkan hambatan yang lebih besar bagi negara NSB untuk maju dan berkembang. Keadaan ini disebut backwash effect.

Kemunculan backwash effect yang menghambat perkembangan NSB disebabkan oleh 3 faktor:

1. Migrasi dari negara miskin ke negara yang lebih maju.

2. Pola aliran modal yang terjadi.

3. Jaringan transportasi yang lebih baik di negara maju. 
Sejalan dengan backwash effect, pembangunan di negara maju dapat pula menimbulkan dorongan yang mempercepat pembangunan di NSB. Myrdal menyebutnya dengan spread effect, yang umumnya berwujud pertambahan permintaan atas produk / bahan baku negara NSB oleh negara maju. Namun perlu diingat bahwa spread effect biasanya lebih kecil daripada backwash effect.

Konsep Myrdal merupakan sebuah kritik terhadap Mahzab Klasik dimana makin melebarnya tingkat pembangunan di berbagai daerah jika kegiatan perekenomian diatur oleh mekanisme pasar.

\section{Teori Perangkap Keseimbangan Tingkat Rendah}

Nelson (1956) mensyaratkan sejumlah kondisi yang harus dipenuhi suatu perekenomian untuk dapat melepaskan diri dari perangkap keseimbangan rendah:

1. Adanya lingkungan sosial politik yang kondusif di negara bersangkutan.

2. Struktur sosial masyarakat harus diubah dengan memberikan penekanan pada adanya efisiensi dan semangat kewirausahaan. 
3. Beberapa langkah harus dijalankan pemerintah untuk mengubah distribusi pendapatan, tetapi pada saat yang bersamaan juga memungkinkan terjadinya akumulasi kekayaan oleh para investor.

4. Harus ada program investasi yang menyeluruh dari pemerintah.

5. Perekonomian harus meningkatkan jumlah pendapatan dan modal yang mereka miliki, salah satunya melalui dana yang didapat dari luar negeri.

6. Perlunya diterapkan teknologi produksi yang dapat lebih memanfaatkan sumber daya yang dimiliki.

\section{Strategi Upaya Minimum Kritis}

Liebenstein (1957) mengajukan tesis yang menyatakan bahwa sebagian besar NSB dicengkeram lingkaran setan kemiskinan yang membuat mereka tetap berada pada tingkat pendapatan per kapita yang rendah. Jalan keluar dari kebuntuan tersebut adalah dengan melakukan upaya minimum yang akan meningkatkan pendapatan perkapita secara berkesinambungan.

Menurut Liebenstein, setiap perekonomomian akan tunduk pada setiap "hambatan" dan "rangsangan" yang 
terjadi. Hambatan akan menurunkan pendapatan per kapita dan rangsangan cenderung menaikan pendapatan per kapita.

Dalam banyak kasus, tingkat pendapatan per kapita berfungsi sebagai faktor pendorong pendapatan, sedangkan tingkat pertumbuhan penduduk merupakan faktor penghambat pendapatan. Bagi pembangunan berkesinambungan, investasi awal harus diatas tingkat minimum tertentu agar dapat menghasilkan tingkat pendapatan perkapita yang cukup besar untuk menghadapi kekuatan penghambat tersebut.

Liebenstein membagi “hambatan" perekenomian menjadi 3 faktor, yaitu:

1. Pertumbuhan penduduk yang tak terkendali

2. Skala disekonomis internal, yang timbul akibat tak dapat dibaginya faktor produksi

3. Skala disekonomis eksternal, yang timbul akibat adanya ketergantungan eksternal, hambatan budaya, dan kelembagaan di NSB

Dalam menjelaskan "rangsangan", Liebenstein membedakan rangsangan pertumbuhan kedalam dua jenis, yaitu: 
1. Kegiatan zero sum yang tidak meningkatkan pendapatan nasional tetapi hanya bersifat upaya distributif.

2. Kegiatan positive sum yang berarti terdapat upaya signifikan dalam pengembangan pendapatan nasional.

Menurut Liebenstein, hanya kegiatan positive sum yang dinilai mampu menghasilkan pembangunan ekonomi. Namun kondisi yang ada pada NSB seringkali hanya mendorong para pengusahanya untuk terlibat dalam kegiatan zero sum. Contoh kegiatan zero sum:

1. Kegiatan "bukan dagang" untuk menjamin posisi monopolistik, kekuatan politik, dan prestise sosial yang lebih besar.

2. Kegiatan dagang yang membawa ke posisi monopolistik dan tidak menambah sumber agregat.

3. Kegiatan spekulatif yang tidak memanfaatkan tabungan, dan tidak memanfaatkan sumber kewirausahaan. 
4. Kegiatan yang menggunakan tabungan, tetapi investasi yang dilakukan hanya mencakup bidang usaha yang nilai sosialnya sama dengan nol.

\section{E. Strategi Pembangunan Seimbang}

Pembangunan seimbang dapat diartikan sebagai pembangunan berbagai jenis industri secara berbarengan sehingga industri tersebut saling menciptakan pasar bagi yang lain. Strategi ini menghasilkan pembangunan secara serentak dan harmonis di berbagai sektor ekonomi hingga keseluruhan sektor akan tumbuh bersama.

Strategi ini baru berjalan dengan baik saat adanya keseimbangan antara sisi permintaan dan penawaran.

a. Sisi penawaran akan memberikan penekanan pada pembangunan serentak dan harmonis dari barang setengah jadi, bahan baku, sumber daya energi, pertanian, transportasi, dan jasa.

b. Sisi permintaan berhubungan dengan penyediaan kesempatan kerja yang lebih besar darn penambahan pendapatan agar permintaan barang dan jasa akan tumbuh. 
Pembangunan seimbang dapat pula didefinisikan sebagai usaha pembangunan yang bertujuan untuk mengatur program investasi sehingga sepanjang proses pembangunan tidak akan timbul permasalahan dari penawaran dan permintaan.

Istilah pembangunan seimbang diciptakan oleh Nurkse (1956). Tetapi teori tersebut pertama kali dikemukakan oleh Rosenstein - Rodan (1953) dengan nama teori dorongan besar besa (big push theory).

Menurut Rosenstein - Rodan, program industrialisasi di daerah kurang berkembang merupakan solusi jitu untuk menciptakan distribusi pendapatan yang lebih merata sehingga daerah tersebut dapat mengejar ketertinggalannya dari daerah maju. Dalam menekankan dalilnya, Rosenstein Rodan menyatakan bahwa cara kerja "selangkah demi selangkah" tidak akan mampu mendorong perekenomian berhasil melaju dengan mulus. Diperlukan suatu tingkat investasi minimum tertentu untuk dapat menjadi solusi awal dalam mendapatkan eksternalitas ekonomi.

Strategi ini bertujuan untuk menciptakan berbagai jenis industri yang berkaitan erat dengan satu sama lain sehingga 
tiap industri akan memperoleh eksternalitas ekonomi sebagai akibat dari industrialisasi. Menurut Rosenstein - Rodan, adanya pembangunan industri secara besar besaran akan mampu menciptakan tiga jenis eksternalitas ekonomi, yaitu:

a. Eksternalitas yang diakibatkan oleh adanya perluasan pasar

b. Eksternalitas yang tercipta karena lokasi industri yang saling berdekatan

c. Eksternalitas yang terjadi karena adanya industri lain dalam perekenomian tersebut.

Jika Rosenstein - Rodan mencetuskan strategi pembangunan yang menekankan sisi permintaan, Scitovsky mencetuskan strategi pembangunan dari sisi penawaran. Scitovsky (1956) menyebutkan bahwa eksternalitas ekonomi dapat diartikan sebagai peningkatan efisiensi yang terjadi pada suatu industri sebagai akibat dari adanya perbaikan teknologi pada industri lain.

Di sisi lain, hubungan saling ketergantungan antara berbagai industri dapat menciptakan eksternalitas ekonomi terkait keuangan, yaitu keuntungan yang diperoleh perusahaan yang disebabkan oleh tindakan dari perusahaan 
lain. Dengan kata lain, keuntungan suatu perusahaan bukan saja tergantung dari efisiensi penggunaan faktor produksi dan tingkat produksi perusahaan tersebut, tetapi juga tergantung dari penggunaan faktor produksi dan tingkat produksi perusahaan lain yang terkait erat dengan perusahaan tersebut.

Lebih lanjut, Scitovsky memberikan gambaran, misal Industri $\mathrm{X}$ melakukan sebuah investasi untuk memperluas kegiatannya, maka tindakan tersebut akan memberikan eksternalita ekonomi pada beberapa jenis industri lainnya seperti:

1) Industri yang menggunakan industri $X$ sebagai bahan baku industri mereka, karena harga lebih murah.

2) Industri yang menghasilkan bahan baku bagi industri $X$, karena permintaan dan harga komoditi bahan baku akan naik.

3) Industri yang menghasilkan barang komplementer untuk barang yang diproduksi industri $\mathrm{X}$, jumlah permintaan barang komplementer juga ikut bertambah. 
4) Industri yang menghasilkan barang yang dibutuhkan oleh orang yang mengalami pertambahan pendapatan.

5) Industri yang menghasilkan barang subtitusi atas bahan baku yang digunakan oleh industri X.

Sementara pendapat dari Lewis (1954), menekankan perlunya pembangunan seimbang yang didasarkan pada keuntungan yang diperoleh dari adanya saling ketergantungan antara berbagai sektor, yaitu sektor pertanian dan sektor industri, serta sektor dalam dan luar negeri.

Lewis menyatakan akan timbul banyak masalah jika usaha pembangunan hanya dipusatkan pada satu sektor saja karena akan menimbulkan ketidakstabilan dan gangguan terhadap kegiatan ekonomi. Lewis memberikan gambaran betapa pentingnya upaya pembangunan yang menjamin adanya keseimbangan antara berbagai sektor industri. Misal terdapat inovasi dalam teknologi produksi bahan pangan untuk kebutuhan domestik.

Tidak semua ahli ekonomi menyetujui praktik strategi pembangunan seimbang. Para ahli ekonomi beranggapan bahwa strategi pembangunan seimbang membutuhkan 
tingkat investasi yang tinggi. Di NSB yang memiliki pendapatan yang terbatas tidak akan mungkin mampu melakukan strategi ini secara sempurna. Kritik terhadap Strategi pembangunan seimbang:

1. Peningkatan biaya

2. Tidak menaruh perhatian pada penurunan biaya

3. Adanya kecendrungan hubungan subtitutif antar industri

4. Dianggap gagal sebagai teori pembangunan

5. Di luar kemampuan NSB

6. Kelangkaan sumber daya di NSB

7. Adanya disproporsi faktor di NSB

8. Investasi secara besar besaran bukanlah solusi

9. Tidak mempertimbangkan faktor perencanaan

10. menimbulkan eksternalitas negatif

\section{F. Strategi Pembangunan Tak Seimbang}

Asumsi utama yang digunakan dalam strategi pembangunan tak seimbang adalah; tidak ada satupun NSB yang memiliki modal dan sumberdaya sedemikian besar. Karena itu, investasi seyogyanya dilakukan pada sektor yang terpilih daripada secara serentak di seluruh sektor ekonomi. 
Pemilihan pengembangan pada sektor atau industri dimaksudkan untuk memfokuskan pengembangan dan segera memberikan keuntungan ekonomis. Dengan demikian, perekenomian akan bergerak dari lintasan pembangunan tak seimbang ke arah pembangunan seimbang.

Menurut Hirschman (1958) pembangunan tak seimbang lebih bertujuan untuk mempercepat pembangunan di NSB, didasarkan beberapa pertimbangan:

1) Secara historis, proses pembangunan ekonomi memiliki corak yang tidak seimbang.

2) Melakukan efisiensi dalam penggunaan sumber daya yang tersedia

3) Pembangunan tak seimbang berpotensi menimbulkan bottlenecks, tetapi hal tersebut dinilai sebagai pendorong bagi pembangunan selanjutnya.

Persoalan mendasar yang dianalisis oleh Hirschman dalam strategi pembangunan tidak seimbang adalah bagaimana cara untuk menentukan proyek pembangunan yang harus didahulukan berdasarkan prioritas tertentu.

Argumen dari Hirshman dilandasi bahwa proyek pembangunan akan memerlukan penggunaan modal dan 
sumber daya yang tak sedikit, seringkali melebihi modal dan sumber daya yang tersedia, maka diperlukan usaha pengalokasian sumber daya yang efektif dan efisien. Cara pengalokasian sumber daya dibagi menjadi 2:

1) Cara pilihan pengganti (substitution), bertujuan untuk menentukan apakah proyek A atau B yang dilaksanakan

2) Cara pilihan penundaan (postponement), bertujuan untuk memilih proyek berdasarkan urutan yang akan dilaksanakan.

Hirschman lebih memusatkan analisisnya pada cara yang kedua. Berdasarkan prinsip postponement, Hirschman menganalisis masalah alokasi sumber daya sektor prasaran / social overhead capital (SOC) dengan sektor produktif yang langsung menghasilkan barang yang dibutuhkan masyarakat / direct productive activities (DPA). Menurut Hirschman, terdapat 3 macam pendekatan dalam pengembangan sektor prasarana dan sektor produktif:

a. Pembangunan seimbang antara kedua sektor.

b. Pembangunan tidak seimbang dimana sektor prasarana lebih ditekankan. 
c. Pembangunan tidak seimbang dimana sektor produktif lebih ditekankan.

Hirschman dalam konsepnya mengenai strategi pembangunan menguraikan dua pilihan orientasi kebijakan dallam alokasi investasi:

1. Orientasi kebijakan yang mendahulukan perkembangan DPA, baru kemudian diikuti oleh SOC. Pendekatan ini disebut pembangunan melalui kekurangan (development via shortage).

2. Orientasi kebijakan yang mendahulukan perkembangan SOC, baru kemudia diikuti oleh DPA. Pendekatan ini disebut pembangunan melalui kapasitas berlebih (development via excess capacity).

Di sebagian besar NSB program pembangunan sering lebih ditekankan pada pembangunan prasarana untuk mempercepat pembangunan sektor produktif. Hirschman tidak sependapat dengan pandangan tersebut. Dengan motivasi masyarakatnya yang terbatas, maka lebih baik menggunakan "pembangunan melalui kekurangan" daripada "pembangunan melalui kapasitas berlebih". Dengan kata lain, dalam setiap negara atau daerah dimana jumlah 
pengusahanya terbatas, orientasi yang paling tepat adalah mendahulukan pembangunan sektor produktif, karena akan menghindari pemborosan penggunaan prasarana.

Selama masa orde baru (1967) sampai sekarang, pembangunan di Indonesia didominasi oleh pembangunan SOC. Dengan ketersediaan prasarana saat ini, sudah saatnya Indonesia mempertimbangkan untuk mengganti strateginya ke "pembangunan melalui kekurangan", yang menitikberatkan perencanaan kegiatan ekonominya sendiri.

Industri apa yang harus dikembangkan agar investasi yang dilakukan di sebuah sektor dapat menunjang investasi di sektor lain?

Chenery dan Watanabe membedakan industri dalam 4 golongan: (1) industri barang setengah jadi, (2) industri barang setengah jadi sektor primer, (3) industri barang jadi, dan (4) industri barang jadi sektor primer. Semakin tinggi urutan industri tersebut, semakin tinggi kemampuan yang dimiliki industri tersebut untuk mendorong perkembangan industri lainnya.

Hirschman berpendapat bahwa dorongan yang diciptakan oleh keterkaitan ke belakang lebih besar daripada dorongan 
yang ditimbulkan keterkaitan ke depan. Maka dari itu, dalam menentukan prioritas, Hirschman lebih mendahulukan industri yang memiliki keterkaitan kebelakang yang lebih tinggi. Sehingga dapat disimpulkan bahwa sektor industri setengah jadi mempunyai kemampuan yang lebih tinggi untuk merangsang pengembangan investasi di sektora lain dibandingkan sektor industri produk akhir.

Seperti yang telah dibahas sebelumnya, Hirschman menyadari bahwa sektor industri barang setengah jadi memang memiliki kemampuan besar untuk mendorong investasi di sektor lain. Namun pasar bagi produknya masih sangat terbatas sehingga sektor tersebut belum bisa benar benar dikembangkan pada tahap awal pembangunan ekonomi, maka sebaiknya sektor industri yang menghasilkan barang jadi yang dikembangkan terlebih dahulu. Industri tersebut umumnya disebut dengan industri barang konsumsi (consumer goods industries).

Akhirnya dapat ditarik kesimpulan bahwa menurut pandangan Hirschman, tahap industrialisasi yang ideal bagi pembangunan ekonomi NSB adalah: (1) tahap perkembangan industri barang konsumsi, (2) tahap perkembangan industri 
barang setengah jadi, dan (3) tahap perkembangan industri barang modal.

Terlepas dari itu semua, konsep pembangunan seimbang juga tidak luput dari beberapa kritik dan keterbatasan:

1) Kurangnya perhatian dalam komposisi, arah dan waktu pertumbuhan tidak seimbang.

2) Mengabaikan kemungkinan timbulnya konflik internal.

3) Kurangnya sumber daya yang dimiliki NSB.

4) Rendahnya mobilitas sumber daya NSB.

5) Adanya ancaman inflasi.

6) Terlalu banyak penekanan pada investasi.

\section{G. Soal Soal}

1. Gambarkan bagan lingkaran kemiskinan menurut pemahaman Anda!

2. Berikan contoh kegiatan ekonomi positive sum dan zero sum!

3. Dalam proses pembangunan di Indonesia, lebih baik menggunakan strategi pembangunan seimbang atau strategi pembangunan tak seimbang? Jelaskan! 


\section{Perencanaan dan}

\section{Pembangunan Ekonomi}

\section{A. Sejarah Perkembangan Perencanaan}

Pasca Perang dunia ke II, perhatian terhadap perencanaan pembangunan meningkat pesat. Perkembangan perhatian tersebut disebabkan 3 faktor utama:

1. Hasrat dan ambisi NSB untuk segera membangun ekonomi negaranya, meningkatkan kesejahteraan masyarakatnya, dan mengejar ketertinggalan dari negara negara maju.

2. Perkembangan perencanaan ekonomi yang sistematis di negara negara sosialis pada masa pasca PD II. Pada masa itu, Uni Soviet adalah negara pertama yang menerapkan sistem pembangunan lima tahun.

3. Adanya pengalaman perencanaan di Amerika dan Eropa selama PD II berlangsung (war time planning). Pengalaman tersebut menunjukan perkembangan 
ekonomi yang tidak semata berlandaskan kekuatan pasar, tetapi terdapat kekuatan lain yang dinilai mampu menentukan kinerja perekenomian, yaitu pemerintah.

\section{B. Pengertian, Unsur, dan Fungsi Perencanaan}

Menurut beberapa ahli, pengertian dari perencanaan pembangunan adalah:

a. Suatu usaha sadar, terorganisasi, dan terus menerus guna memilih alternatif yang terbaik dari sejumlah alternatif dalam mencapai satu tujuan tertentu (Waterson, 1965).

b. Suatu proses berkesinambungan yang mencakup proses pengambilan keputusan atau memilih berbagai alternatif penggunaan sumber daya untuk mencapai tujuan tertentu pada masa mendatang (Conyers \& Hills, 1994).

Perlu diketahui bahwa "perencanaan" dan "rencana" memiliki perbedaan dalam definisinya.

- Perencanaan didefinikan sebagai suatu kegiatan organisasional yang disengaja untuk memberikan suatu strategi optimal dari tindakan nyata di masa 
depan dalam mencapai tujuan atau memecahkan masalah kompleks.

- Rencana merupakan produk dari kegiatan perencanaan, yaitu sesuatu yang menjadi pedoman dan arahan untuk mencapai sasaran yang telah ditetapkan.

Dari definisi yang telah disebutkan, terdapat empat elemen dasar dari sebuah perencanaan:

1. Merencanakan berarti memilih. Perencanaan merupakan proses memilih antara berbagai kegiatan yang ingin dilaksanakan, karena dengan segala keterbatasan sumber daya yang dimiliki maka tidak semua kegiatan dapat dilakukan dan dicapai secara bersamaan.

2. Perencanaan merupakan pengalokasian sumber daya, mencakup pengambilan keputusan mengenai bagaimana pengalokasian sumber daya yang tersedia sebaik baiknya.

3. Perencanaan merupakan alat untuk mencapai tujuan. Masalah yang sering dihadapi perencana 
pembangunan yaitu tujuan pembangunan kurang didefinisikan secara tepat dan tegas.

4. Perencanaan untuk masa depan. Tujuan dalam perencanaan dirancang agar dapat dicapai pada masa mendatang.

Sebagian besar ekonom memandang perencanaan ekonomi mengandung arti adanya pengendalian dan pengaturan perekenomian dengan sengaja oleh pemerintah untuk mencapai tujuan tertentu dalam jangka waktu tertentu. Berikut adalah beberapa karakteristik perencanaan pembangunan ekonomi:

1. Adanya upaya yang tercermin dalam suatu rencana untuk mencapai pertumbuhan sosial ekonomi yang mantap.

2. Adanya upaya yang tercermin dalam suatu rencana untuk meningkatkan pendapat per kapita.

3. Adanya upaya yang bertujuan untuk mengadakan diversifikasi struktur ekonomi.

4. Adanya upaya yang bertujuan untuk perluasan kesempatan kerja. 
5. Adanya upaya yang bertujuan untuk pemerataan pembangunan.

6. Adanya upaya yang bertujuan untuk pembinaan lembaga ekonomi masyarakat agar lebih menunjang kegiatan pembangunan.

7. Adanya upaya terus menerus untuk menjaga stabilitas ekonomi dalam negeri.

Selain itu, menurut Arsyad (2001), perencanaan pembangunan juga harus mengandung beberapa unsur pokok, yaitu:

1. Adanya kebijakan atau strategi dasar dalam perencanaan pembangunan.

2. Adanya kerangka perencanaan di tataran makro.

3. Adanya perkiraan mengenai sumber pembangunan, khusunya sumber pembiayaan pembangunan.

4. Adanya uraian mengenai kerangka kebijakan yang konsisten, misalnya kebijakan fiskal, penganggaran, moneter, harga, serta kebijakan sektoral lainnya.

5. Perencanaan pembangunan adalah program investasi yang dilaksanakan secara sektoral. 
6. Perencanaan pembangunan adalah administrasi pembangunan yang mendukung usaha perencanaan dan pelaksanaan pembangunan tersebut.

Perencanaan pembangunan menurut Basri (2005) memiliki beberapa fungsi:

1. Perencanaan akan menciptakan mekanisme pengarahan dan pedoman bagi pelaksanaan kegiatan pembangunan.

2. Perencanaan memungkinkan kita melakukan perkiraan tentang potensi, prospek pertumbuhan, hambatan serta resiko di masa depan.

3. Perencanaan memberikan suatu peluang untuk melaksanakan pilihan terbaik.

4. Perencanaan menuntut kita melakukan penyusunan skala prioritas.

5. Perencanaan dapat pula dipandang sebagai alat pengukur pengawasan atau evaluasi.

\section{Perlunya Perencanaan Ekonomi di Negara Berkembang}


Di dalam ilmu ekonomi, kita mengenal istilah stable equilibrium dimana jika keseimbangan berubah, akan timbul suatu reaksi dalam bentuk perubahan ke arah berlawanan dan pada akhirnya akan kembali ke keseimbangan semula.

Sayangnya teori ini tidak berlaku pada sistem sosial. Dalam sistem sosial tidak ada kekuatan yang secara otomatis mengembalikan keadaan yang tidak stabil menjadi stabil. Hal ini menunjukan bahwa suatu proses sosial cenderung bersifat kumulatif.

Suatu contoh dari proses kumulatif adalah lingkaran kemiskinan. Untuk dapat keluar dari lingkaran tersebut, diperlukan peningkatan laju pertumbuhan ekonomi. Laju pertumbuhan didapat dari pembentukan modal dengan cara mendorong tingkat pendapatan, tabungan, dan investasi. Tetapi pembentukan modal sering kali menghadapi kendala, salah satunya kemiskinan, sehingga menyebabkan rendahnya tingkat pendapatan, tabungan, dan produktifitas.

Terdapat dua metode yang dapat dikembangkan untuk memotong lingkaran kemiskinan: (1) melakukan pembangunan terencana dengan mencari modal dari luar negeri, atau dikenal dengan istilah industrialisasi yang 
diproteksi, dan (2) dengan cara menghimpun tabungan wajib dalam negeri, atau dikenal dengan istilah industrialisasi dengan kemampuan sendiri.

Dasar pemikiran tentang perlunya sebuah perencanaan di NSB adalah untuk memperbaiki dan memperkuat mekanisme pasar. Mekanisme pasar yang tidak sempurna di NSB seringkali menyebabkan perekenomian hanya didominasi oleh sektor non uang. Perencanaan sangat dibutuhkan untuk menghapus ketidaksempurnaan pasar sehingga pemanfaatan sumberdaya dapat lebih efisien. Kebutuhan perencanaan NSB juga didorong oleh adanya keinginan untuk dapat mengurangi angka pengangguran sehingga dapat mengatasi ketimpangan distribusi pendapatan, sekaligus untuk meningkatkan pendapatan nasional dan pembangunan negara secara keseluruhan

\section{Proses Perencanaan Ekonomi}

Pada dasarnya, proses perencanaan pembangunan ekonomi dapat dibagi ke dalam empat tahap. Empat tahap tersebut ditetapkan dalam satu rangkaian yang dimulai pada saat tujuan ditetapkan oleh para pemimpin politik dan 
diterjemahkan dalam target kuantitatif untuk mencapai sasaran pertumbuhan ekonomi

Tahap pertama, pemimpin politik menetapkan prioritas tujuan untuk mengarahkan para perencana jika terjadi beberapa konflik tujuan dalam pemenuhan rencana pembangunan nasional. Hal ini terjadi umumnya karena pemimpin politik di sebuah negara menetapkan target kenaikan untuk lebih dari satu atau banyak tujuan sekaligus.

Tahap kedua, mengukur ketersediaan sumber daya yang terbatas selama periode perencanaan tersebut, misalnya tingkat tabungan, bantuan luar negeri, penerimaan pemerintah, penerimaan ekspor, tenaga kerja yang terlatih, dll. Selain sumber daya, keterbatasan administrasi dan organisasi juga merupakan constraints yang kuat.

Tahap ketiga, usaha ekonomi ditujukan untuk memilih berbagai cara (kegiatan dan alat) yang dapat dipergunakan untuk mencapai tujuan nasional. Pada tahap ini, ditetapkan proyek investasi seperti jalan raya, pabrik, pusat kesehatan, kebijakan harga (seperti nilai kurs, tingkat bunga, upah, pengaturan pajak, subsidi) untuk mengembangkan tujuan pembangunan nasional. 
Tahap keempat, pada tahap ini perencanaan merupakan sebuah proses pemilihan kegiatan yang layak dilakukan dan penting, agar dapat mencapai tujuan nasional tanpa adanya kendala sumberdaya dan organisasional. Hasil dari proses ini adalah strategi pembangunan yang akan dilakukan selama beberapa tahun (biasanya 5 tahun).

Rangkaian perencanaan ini hanya akan dapat berjalan dengan baik jika para pemipin politik mampu menetapkan tujuan sosial dan prioritas yang cukup jelas bagi para perencana. Sayangnya para pemimpin politik tidak selalu mampu berbuat demikian. Mereka lebih suka menggunakan penyataan mengenai tujuan besar tetapi kurang jelas dan terarah untuk mendongkrak popularitas mereka.

\section{E. Sistem Perencanaan Ekonomi: Perencanaan Kapitalis}

Salah satu kelemahan mendasar dari sistem mekanisme pasar yang bebas adalah kemungkinan ketidakstabilan pada perekenomian. Ketidakstabilan tercermin oleh adanya fluktuasi tingkat tinggi pada pendapatan nasional dan tingkat kesempatan bekerja, maka pemerintah harus berperan aktif dalam menciptakan keadaan yang stabil agar laju 
perekenomian masih tetap terjaga. Instrumen utama yang digunakan adalah kebijakan moneter, perpajakan, dan hubungan dagang luar negeri.

Tingkat kesempatan kerja dan tingkat pendapatan yang tinggi diupayakan dengan kebijakan ekspansi moneter, peningkatan pengeluaran pemerintah, dan penyesuaian tarif pajak. Inflasi dapat diatasi melalui kebijakan fiskal dan penyesuaian suku bunga. Gejolak pada neraca pembayaran dapat dinetralisir melalui pengendalian devisa, kuota impor, dan pajak. Instrumen tersebut meskipun dapat dilakukan secara aktif, tetapi bersifat tidak langsung.

\section{F. Sistem Perencanaan Ekonomi: Perencanaan Sosialis}

Perencanaan perekenomian secara sosialis bercirikan dimana pemerintah secara aktif dan langsung mengendalikan gerak perekenomian. Sistem ini seringkali dikaitkan dengan perekeonomian ala Sovyet dan Tiongkok.

Perbedaan mendasar antara perencanaan kapitalis dan perencanaan sosialis adalah rangsangan (inducement) versus pengendalian (control). Sumber daya yang tersedia tidak dialokasikan atas tarik menarik antara penawaran dan permintaan, melainkan dialokasikan sesuai dengan kebutuhan 
akan material, tenaga kerja, dan modal yang telah direncanakan sebelumnya.

Pada sistem kapitalis, pemerintah hanya berusaha mencegah perekenomian tidak keluar dari pertumbuhan yang stabil melalui instrument kebijakan aktif tapi tak langsung. Sementara pada sistem sosialis, kebijakan dibuat bukan hanya untuk menetapkan sasaran kemajuan ekonomi, tetapi juga untuk mengendalikan secara langsung kegiatan dari seluruh unit produksi dalam perekenomian secara keseluruhan.

\section{G. Sistem Perencanaan Ekonomi: Perencanaan Campuran}

Perekonomian campuran merupakan sebuah perekenomian yang bercirikan adanya lingkungan kelembagaan dimana sebagian sumber daya produktif dimiliki dan dikelola oleh pihak swasta dan sebagian lainnya dimiliki dan dikelola pemerintah.

Perekonomian campuran juga dicirikan oleh adanya pengaruh pemerintah yang sangat besar pada hampir semua kegiatan ekonomi. Terdapat dua aspek utama dalam perencanaan sistem campuran 
1. Penggunaan tabungan masyarakat dan pinjaman luar negeri dilakukan dengan sengaja oleh pemerintah untuk melaksanakan investasi pada proyek pemerintah yang diharapkan memberikan sumbangan kemajuan ekonomi dalam jangka panjang.

2. Adanya kebijakan pemerintah untuk mempermudah, merangsang, mengarahkan, bahkan mengendalikan kegiatan ekonomi swasta untuk menjamin pola hubungan yang serasi antara keinginan pihak swasta dan rencana perekenomian yang dirumuskan oleh pemerintah pusat.

\section{H. Perencanaan Pembangunan di Indonesia}

Pada masa Orde Lama, strategi pembangunan didasarkan perencanaan pembangunan lebih menekankan pada usaha pembangunan sosial dan politik, hal ini sesuai dengan situasi saat itu yaitu masa mempertahankan kemerdekaan Republik Indonesia sehingga belum memungkinkan untuk pembangunan secara riil.

Tahun 1947 dimulai suatu perencanaan beberapa sektor ekonomi dan diberi nama Plan Produksi Tiga Tahun RI untuk 
tahun 1948, 1949, dan 1950, ditujukan terhadap bidangbidang pertanian, peternakan, perindustrian dan kehutanan. Tahun 1956 sampai 1960, pemerintah berhasil merumuskan dan menjalankan Rencana Pembangunan Lima Tahun.

Pada masa presiden soekarno, MPR sementara mengeluarkan Ketetapan MPRS No.IV/MPRS/1963 tentang Pedoman-Pedoman Pelaksanaan Garis-Garis Besar Haluan Negara dan Haluan Pembangunan Nasional Semesta Jangka Panjang.

Pemerintah Orde Baru pada awal mulanya, mewarisi kemerosotan ekonomi yang ditinggalkan oleh pemerintahan sebelumnya. Program stabilisasi dan rehabilitasi mulai dilakukan dengan kerangka

1. Dalam jangka panjang (pembangunan secara utuh dan terpadu)

2. Dalam jangka menengah (pembangunan ekonomi dan sosial untuk menciptakan kesejahteraan dan keadilan sosial)

Mulai tahun 1 April 1969, pemerintah Orde Baru menciptakan landasan untuk pembangunan yang disebut sebagai Rencana Pembangunan Lima Tahun (Repelita 
1). Repelita pertama berfokus pada rehabilitasi prasarana penting untuk pengembangan iklim usaha dan investasi. Pembangunan sektor pertanian diberi prioritas, untuk memenuhi kebutuhan pangan sebelum membangun sektorsektor lain.

Repelita II (1974-1979) dan Repelita III (1979-1984), fokus pada pencapaian pertumbuhan ekonomi, stabilitas nasional, dan pemerataan pembangunan dengan penekanan pada sektor pertanian dan industri yang mengolah bahan mentah menjadi bahan baku. Tahun 1984, Indonesia berhasil mencapai status swasembada beras.

Fokus Repelita IV (1984-1989) dan Repelita V (1989-1994), selain berusaha mempertahankan kemajuan di sektor pertanian, juga mulai bergerak menitikberatkan pada sektor industri khususnya industri yang menghasilkan barang ekspor, industri yang menyerap tenaga kerja.

Ketiadaan Garis Besar Haluan Negara (GBHN) di era reformasi, telah mendorong Presiden Susilo Bambang Yudhoyono menghadirkan UU No 17/2007, tentang Rencana Pembangunan Jangka Panjang (RPJP) Nasional Tahun 20052025. Strategi pembangunan ini disesuaikan dengan konteks 
keunggulan sumber daya di Indonesia, dengan memadukan pengelolaan sumber daya alam (nature resources), kearifan lokal (knowledge), dan kekayaan budaya (culture).

Dengan berdasar pada Undang-undang Otonomi Daerah (No. 22 tahun 1999), pemerintahan SBY juga membuat Rencana Pembangunan Jangka Menengah Nasional (RPJMN) Tahun 2010-2014 yang mendorong percepatan pembangunan wilayah-wilayah di luar pulau jawa, sambil menjaga momentum pertumbuhan ekonomi di pulau jawa.

Di era presiden Joko Widodo, pemerintah merumuskan program Nawa Cita yang menawarkan agenda prioritas menuju Indonesia yang berdaulat dan mandiri dalam bidang ekonomi. Program nawa cita memprioritaskan 3 agenda pembangunan yang harus dicapai untuk pembangunan ekonomi di Indonesia: (1) pembangunan infrastruktur, (2) integrasi rencana pembangunan antar pemerintah pusat sampai ke pemerintah desa, mendatangkan investor untuk percepatan pembangunan.

\section{Soal-Soal}

1. Jelaskan mengapa negara berkembang perlu merencanakan pembangunan ekonominya! 
2. Jelaskan fungsi perencanaan!

3. Jelaskan perbedaan dari "perencanaan" dan "rencana" dalam pembangunan ekonomi!

4. Jelaskan proses proses dalam perencanaan ekonomi!

5. Menurut pendapat Anda, sistem perencanaan apa yang cocok diterapkan di Indonesia? Jelaskan jawaban Anda! 


\section{Tabungan Dalam Negeri}

\section{A. Investasi dan Pertumbuhan Ekonomi}

Studi mengenai kontribusi relatif dari modal terhadap pertumbuhan ekonomi menunjukan bahwa dampak pembentukan modal berpengaruh besar terhadap pertumbuhan ekonomi NSB, khususnya pada masa awal pembangunan ekonomi. Hasil studi di beberapa negara berpenghasilan menengah pada tahun 90an seperti Meksiko, Korea Selatan, dan Filipina menunjukan bahwa modal fisikal mampu mempu memberikan kontribusi sebesar 0.25 sampai 0.30 dari pertumbuhan ekonomi, atau paling banyak 0.50 dalam NSB pada umumnya.

Salah satu isu penting dalam pembangunan ekonomi negara, khususnya NSB adalah masalah efisiensi alokasi sumber daya ekonomi yang dimilikinya. Pembangunan ekonomi tanpa memeperhatikan efisiensi akan dianggap kurang optimal karena pemborosan sumber daya. Dalam jangka panjang, inefisiensi akan mempengaruhi ketahanan 
ekonomi di sebuah negara. Salah satu indikator makro dari tingkat efisiensi suatu perekenomian adalah angka rasio dari investasi terhadap GDP atau sering disebut incremental Capital Output Ratio (ICOR). Semakin rendah rasio tersebut, semakin tinggi efisiensi investasi.

Besarnya ICOR tergantung pada struktur harga dan orientasi pembuat keputusan di sektor pemerintah. Semakin tinggi nilai ICOR, semakin tinggi pula yang modal yang dibutuhkan untuk menghasilkan kenaikan GDP sebuah negara (yang disebabkan karena faktor inefisiensi dari penggunaan modal tersebut).

\begin{tabular}{|c|c|c|}
\hline $100 \mathrm{ne}$ & 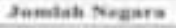 & Nosen Nroura fontera bleim) \\
\hline $0,1+0,00$ & 6 & 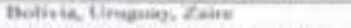 \\
\hline $1,0=1,40$ & 17 & 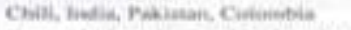 \\
\hline $1,8-1,4,69$ & ? & Kenga Indonesia, Jantica, Jeinube \\
\hline $2.9+2.46$ & 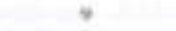 & 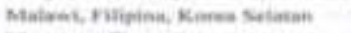 \\
\hline $2,5 \times 3,90$ & 2 & Mramuat, Twhisoute \\
\hline $3,0=3,46$ & 2 & Mendeatus \\
\hline $3,5=3,0 y$ & $\mathbf{3}$ & Vimilunia, Tioger \\
\hline $4.0=4.46$ & 3 & Henems, Sinckepera \\
\hline $4.3+4.68$ & 1 & Simarnevia \\
\hline $\mathrm{Di}=4 \mathrm{n}=\mathrm{s}$ & 1 & Nemai Cladier: \\
\hline
\end{tabular}

Tabel 5.1

Rerata ICOR di 41 NSB 1990 - 1993

Sementara di Indonesia, diketahui bahwa rata rata ICOR periode 1993 - 2002 mencapai angka 4.47. Tingginya ICOR menunjukan ketidakefisiensian perekenomian kita. Misalnya 
inefiesiensi di sektor pemerintahan umum, tingginya angka ICOR menghasilkan dua kesimpulan:

1. Terjadinya ketidakefisiensian pada sistem birokrasi (hyperbureucracy) di negeri ini sehingga menimbulkan high cost economy.

2. Merupakan sebuah konsekwensi dari peran pemerintah sebagai penyedia layanan publik, dimana manfaat dan nilai ekonominya tidak dapat dirasakan seketika.

\begin{tabular}{|l|c|}
\hline \multicolumn{1}{|c|}{ Sektor } & Periode (1993-2002) \\
\hline Pertanian & 4,18 \\
Pertambangan \& Galian & 2,20 \\
Industri Pengolahan & 1,28 \\
Pengilangan Minyak & 1,33 \\
Listrik, gas, dan air minum & 18,16 \\
Konstruksi & 0,65 \\
Pemerintahan umum & 71,58 \\
Jasa-jasa & 5,88 \\
\hline Rata-rata & 4,47 \\
\hline
\end{tabular}

Tabel 5.2

ICOR sektoral di Indonesia

Rerata tahun 1993 - 2002 
Bagaimana mereduksi nilai ICOR?

Sebagai titik awal, penggunaan modal yang efisien membutuhkan keadaan dimana modal tersebut dapat dikombinasikan dengan faktor produksi lain yang tersedia dalam proporsi yang selaras.

Namun demikian, perpindahan arus modal melintasi perbatasan geografis tidaklah mudah. Meskipun potensi atas perpindahan tersebut sangat besar, mobilitas sumber daya modal seringkali dihambat oleh barrier to entry, seperti adanya batasan tentang kepemilikan modal asing. Barrier to exit juga dapat manjadi hambatan bagi perpindahan arus modal, seperti adanya pajak atas aliran modal keluar, dll.

\section{B. Sumber Tabungan Dalam Negeri}

Pada umumnya, NSB membiayai rasio investasi - GDP mereka yang tinggi dengan mengintensifkan usaha mobilisasi tabungan dari berbagai sumber. Jumlah tabungan dari suatu negara (S) secara sederhana merupakan akumulasi dari tabungan domestik (Sd) dan tabungan luar negeri (Sf).

Tabungan domestik (Sd) dibagi menjadi dua komponen: tabungan pemerintah (Sg) dan tabungan swasta (Sp). 
Tabungan pemerintah diperoleh dari surplus penerimaan pemerintah, sementara tabungan swasta diperoleh dari tabungan perusahaan (berupa pajak atas laba perusahaan) dan tabungan rumah tangga (berupa pajak atau deposito atas pendapatan pribadi dan pendapatan non korporasi)

Tabungan luar negeri (Sf) juga berasal dari dua sumber utama yaitu: tabungan pemerintah asing / bantuan luar negeri (Sfo) dan tabungan swasta asing (Sfp) yang terdiri dari investasi asing.

Jadi secara keseluruhan, persamaannya adalah:

$$
S=S d+S f=(S g+S p)+(S f o+S f p)
$$

NSB telah mengintensifkan usaha mobilisasi tabungan sejak tahun 1980. Meskipun banyak NSB yang mengandalkan tabungan luar negeri sebagai sumber utama pembiayaan pembangunan, tabel 5.3 menunjukan kecendrungan kenaikan investasi pada porsi tabungan domestik dari GDP.

Gambaran ini menunjukan bahwa semakin tinggi pendapatan NSB, maka proporsi tabungan domestik dalam pembiayaan investasi semakin tinggi. Kebijakan pemerintah memiliki dampak yang cukup besar bagi kemampuan NSB 
dalam memobilisasi tabungan domestik melalui kebijakan fiskal dan moneter.

\begin{tabular}{|c|c|c|c|c|c|c|}
\hline \multirow[t]{2}{*}{ Negara: } & \multicolumn{2}{|c|}{$\begin{array}{l}\text { Tahengan } \\
\text { Daurstik } \\
(76 \text { dariGDF) }\end{array}$} & \multicolumn{2}{|c|}{ 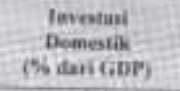 } & \multicolumn{2}{|c|}{$\begin{array}{c}\text { Catah } \\
\text { Sumberdeys }\end{array}$} \\
\hline & 1990 & 2004 & 1990 & 2004 & 16911 & 2914 \\
\hline \multicolumn{7}{|c|}{ Negara Berpendapatan } \\
\hline Rendah: & 15 & $n$ & 21 & 23 & 3 & -1 \\
\hline - Ithioger & 10. & 13 & 12 & 21 & +2 & -8 \\
\hline - Laberia & $\mathrm{Di}$ & 12 & na & 29 & $n / n$ & -17 \\
\hline - Nepal & -10 & 27 & 18 & 26 & -8 & 1 \\
\hline - Bangialesh & 14 & 31 & 17 & 24 & -3 & 7 \\
\hline - Keopa & 19 & 14 & 24 & 18 & -5 & -4 \\
\hline - Kainhoja & 6 & 19 & 8 & 26 & 2 & $+?$ \\
\hline - Tajikistan & 25 & 9 & 34 & 6 & 1 & 3 \\
\hline \multicolumn{7}{|c|}{ Negara Berpendupatai } \\
\hline Menengah: & 26 & 25 & 26 & 26 & 0 & 1 \\
\hline - Snitamia & 17 & 19 & 23 & 25 & -6 & -6 \\
\hline - Tharland & 33 & 31 & 41 & 23 & -8 & 4 \\
\hline - Ampentiana & 13 & 21 & 14 & 19 & -1 & 2 \\
\hline - India & 22 & 2 & 24 & 24 & -2 & 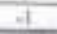 \\
\hline cindangale. & 25 & 24 & dit & 21 & +1 & -1 \\
\hline - Mtalyzaia & 30 & 35 & 32 & 23 & -2 & 12 \\
\hline - Meksila & 20 & 21 & 21 & 21 & 3 & 0 \\
\hline - Filipine & 20 & 35 & 24 & 17 & 4 & 2ii \\
\hline
\end{tabular}

Tabel 5.3

Tingkat Tabungan Domestik

di Beberapa Negara NSB 1990 - 2004

Kekuatan-kekuatan utama yang mempengaruhi kepribadian seseorang adalah kekuatan keturunan, kekuatan kebudayaan, kekuatan hubungan keluarga dan kelas sosial atau pendidikan, dan kekuatan lain dari keanggotaan kelompok.

Tabungan pemerintah pada umumnya diperoleh dari surplus penerimaan pajak keseluruhan terhadap konsumsi 
pemerintah. Terbatasnya persediaan tabungan luar negeri memberikan penekanan pada pentingnya mobilisasi tabungan pemerintah. Cara yang paling sering digunakan untuk mengumpulkan tabungan pemerintah adalah dengan meningkatkan rasio pajak. Di satu sisi, tingkat pajak yang tinggi memiliki efek positif yaitu sebagai pendorong pencapaian dasar pembangunan, seperti redistribusi pendapatan. Di sisi lain, rasio yang tinggi tidak selalu menjamin keberhasilan mobilisasi tabungan pemerintah.

Tabungan swasta, dalam banyak penelitian, memainkan peranan penting dalam menunjang proses pembentukan modal dalam negeri. Data dari bank Dunia, menunjukan bahwa banyak diantara NSB mengalami pertumbuhan konsumsi swasta yang cukup pesat. Tetapi seiring dengan peningkatan pendapatan suatu negara, ada kecendrungan bahwa laju pertumbuhan konsumsi swasta menjadi semakin kecil dibandingkan pertumbuhan GDPnya.

\section{Faktor Penentu Tabungan Swasta}

Menurut Todaro (2000), terdapat 2 komponen utama pembentuk tabungan swasta sebuah negara; (1) tabungan rumah tangga, dan (2) tabungan perusahaan. 
Pada dasarnya, teori perilaku tabungan rumah tangga berusaha menjelaskan tiga pola berikut:

1. Dalam suatu negara, pada waktu tertentu, pendapatan yang ditabung oleh rumah tangga berpendapatan tinggi lebih besar daripada rumah tangga yang berpendapatan lebih rendah.

2. Dalam suatu negara, rasio tabungan rumah tangga cenderung konstan sepanjang waktu.

3. Rasio tabungan rumah tangga bervariasi antarnegara tanpa menunjukan adanya hubungan yang jelas dengan pendapatan.

Tabungan perusahaan di NSB relatif kecil disebabkan oleh masih relatif kecilnya sektor perusahaan dalam total perekenomian. Kurang berkembangnya sektor NSB seringkali dipicu oleh minimnya rangsangan dan insentif dalam pengembangan sektor usaha NSB.

Pada NSB berpenghasilan menengah, terdapat beberapa perusahaan domestik berskala besar. Seperti Bavaria di Kolombia, Hyundai di Korea Selatan, Alpostagus di Argentina, Tata di India, Villares di Brazil, dll. Namun jumlahnya yang 
tidak banyak menghasilkan proporsi tabungan domestik yang disumbangkan.

Dalam beberapa NSB, bagian terbesar dari kegiatan sektor swasta di bidang perkebunan, perdagangan, dan manufaktur dilakukan oleh perusahaan keluarga / bukan korporasi. Sebagian besar kegiatannya adalah skala kecil (mempunyai tidak lebih dari 10 pekerja) yang tidak menghasilkan proporsi yang cukup besar di nilai tambah tabungan, meski jumlah mereka sangat banyak.

\section{Sekilas Mengenai Tabungan Dalam Negeri Indonesia}

Indonesia sebagai NSB juga mengalami masalah kesenjangan investasi - tabungan, karena pembangunan ekonomi nasional yang menuntut pada pertumbuhan dan industrialisasi membutuhkan investasi dalam jumlah besar.

Tabel 5.4 menunjukan bahwa kesenjangan tabungan investasi terjadi pada pelita 1 sampai pelita 5 . Seiring dengan dinamika pembangunan, kebutuhan investasi akan mengalami peningkatan. Dari hasil tabel 5.4, dapat disimpulkan bahwa terdapat hubungan positif signifikan antara jumlah investasi dengan GDP. 


\begin{tabular}{|c|c|c|c|c|c|}
\hline Periode & $\begin{array}{l}\text { Tinglat } \\
\text { Tatugan } \\
\text { Donestik }\end{array}$ & $\begin{array}{l}\text { Tindat } \\
\text { lavestai }\end{array}$ & $\begin{array}{l}\text { Kescriangun } \\
\text { Tabungin } \\
\text { Invelsi }\end{array}$ & GDP & $\begin{array}{c}\text { Proponi } \\
\text { Tabungar } \\
\text { Domectix } \\
\text { Terhadep } \\
\text { GD? } \\
\text { Oij }\end{array}$ \\
\hline \multicolumn{6}{|l|}{ Akhit Pelital } \\
\hline$(1973 / 974$ & 498,8 & 1.208 & .9092 & 6.753 & 14 \\
\hline \multicolumn{6}{|l|}{ Ahir Pelisall } \\
\hline$(1978 / 1979)$ & 3.502 .2 & 6704 & 32018 & 32.025 & 109 \\
\hline \multicolumn{6}{|l|}{ Allir Pelia III } \\
\hline (7983/2984) & 12.737 .0 & 23.543 & .10 .8060 & 89.885 & 14,2 \\
\hline \multicolumn{6}{|l|}{ Akhir Pelita IV } \\
\hline (1968)/959) & $33.155,3$ & 58.831 & $.25 .673,3$ & 167.185 & 19,8 \\
\hline \multicolumn{6}{|l|}{ Akthir Pelita V } \\
\hline$(1993 / 994)$ & $92.556,6$ & 106.529 & .13 .9724 & 302018 & 30,6 \\
\hline
\end{tabular}

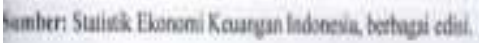

Tabel 5.4

Perkembangan Tingkat Tabungan Domestik, GDP, dan Investasi Selama PELITA I - Pelita V (dalam milyar Rupiah)

Pada tabel 5.5, ditunjukan bahwa kecuali pada pelita 2 dan 3, tingkat tabungan swasta selalu lebih besar dari tabungan pemerintah. Kesenjangan tersebut semakin tajam di pelita 4. hal ini mengindikasikan peranan swasta yang begitu kuat dalam pembentukan modal di tanah air.

Meningkatnya peran dari sektor swasta tak lepas dari serangkaian kebijakan deregulasi yang dibuat pemerintah. 


\begin{tabular}{|c|c|c|c|c|c|}
\hline Proiode & $\begin{array}{c}\text { Tahunges } \\
\text { Peneritial } \\
\text { (tP) }\end{array}$ & $\begin{array}{c}\text { Tabungas } \\
\text { Suasa } \\
\text { (15) }\end{array}$ & $\begin{array}{c}\text { Tatungal } \\
\text { Donchis } \\
\text { (TD) }\end{array}$ & $\begin{array}{l}\text { Prooks } \\
\text { PaTD } \\
(99)\end{array}$ & $\begin{array}{l}\text { Pospini } \\
\text { rsmp } \\
69\end{array}$ \\
\hline \multicolumn{6}{|l|}{ Ablit Pclital } \\
\hline$(09731970)$ & 2379 & 2609 & 4988 & 47,7 & 52,3 \\
\hline \multicolumn{6}{|l|}{ Alar Pein II } \\
\hline (697819\%) & 20883 & 14639 & 3502 & 58,2 & 418 \\
\hline \multicolumn{6}{|l|}{$\frac{(197819 \% 9)}{\text { Akhir Relin III }}$} \\
\hline (36037984) & 7.043 .6 & $5,693,4$ & 12737,0 & 55,3 & 44,7 \\
\hline \multicolumn{6}{|l|}{ Akhir Pela IV } \\
\hline (ask67985) & 3315.5 & 20.89 .8 & 31.155 .3 & 10.0 & 90,0 \\
\hline \multicolumn{6}{|l|}{ (I560/986) } \\
\hline (1993/7994) & 11.662 .1 & 800945 & 92536.6 & 126 & 87.4 \\
\hline
\end{tabular}

Tabel 5.6

Proporsi Tabungan Pemerintah dan Tabungan Swasta Terhadap Tabungan Domestik selama Pelita I - Pelita V

\section{E. Soal Soal}

1. Jelaskan definisi dan kegunaan dari Tabungan Dalam Negeri!

2. Jelaskan secara terperinci mengenai konsep ICOR!

3. Bagaimana mereduksi nilai ICOR? Jelaskan!

4. Jelaskan komponen pembentuk tabungan dalam negeri!

5. Jelaskan komponen pembentuk tabungan swasta! 


\section{Sumber Dana dari Luar Negeri}

\section{A. Bantuan Luar Negeri}

Bantuan luar negeri adalah meliputi bantuan yang bersumber dari pemerintah maupun swasta dari negara lain. Hampir semua bantuan (pinjaman) memiliki syarat yang longgar dengan tingkat bunga rendah dengan jangka waktu pembayaran yang cukup lama, atau bahkan diberikan sebagai hibah. Jenis bantuan dapat dibagi menjadi 2 jenis:

1. Bantuan bilateral, yaitu bantuan yang diberikan secara langsung oleh sebuah negara ke negara lainnya.

2. Bantuan multilateral, yaitu bantuan yang dananya mengalir ke badan internasional (PBB, Bank Dunia, Bank Pembangunan Asia) yang selanjutnya dana tersebut disalurkan / dipinjamkan ke NSB.

Di sisi lain, sumber dana asing terdiri dari 2 elemen:

1. Investasi asing langsung (foreign direct investment / FDI). Yaitu Investasi yang dilakukan oleh perusahaan 
multinasional asing pada perusahaan yang berlokasi di negara tuan rumah. Investasi ini membuat investor asing mengendalikan secara penuh / sebagian dari sistem manajemen perusahaan.

2. Investasi portofolio. Yaitu pembelian obligasi oleh atau saham investor asing, namun investor tersebut tidak ikut mengendalikan manajemen, mereka hanya bertugas menanamkan modal.

Bantuan luar negeri sekarang ini merupakan kelanjutan dari Marshall Plan, dimana pada waktu itu Amerika Serikat menyalurkan bantuan dana kurang lebih 4 tahun guna membantu pembangunan kembali Eropa setalah Perang Dunia 2.

Terdapat 3 macam alasan yang mendasari bantuan luar negeri dari AS tersebut:

a. Terdapat perencanaan yang baik dari Eropa untuk pembangunan ekonominya, sehingga aliran modal dari AS dapat digunakan secara efisien untuk membangun kembali stok modal fisik di Eropa.

b. Banyaknya negara yang baru merdeka dan membutuhkan dana untuk pembangunan. Terdorong 
dari pengalamannya membantu Eropa, AS berusaha menolong negara baru merdeka dengan memberikan bantuan yang sama, terutama pada negara yang siap dengan rencana pembangunannya.

c. Kebijakan bantuan AS bertujuan untuk mendorong negara baru merdeka untuk menerapkan lembaga politik yang demokratis dan perekenomian yang didukung oleh perusahaan swasta, seperti di AS.

\section{B. Lembaga Bantuan Internasional}

\section{Lembaga 1:}

Asian Development Bank (ADB) berdiri tahun 1966, dan bertugas untuk meningkatkan pertumbuhan ekonomi, serta bekerja sama dengan pihak yang berkepentingan di kawasan Asia. Fungsi dan tujuan ADB:

1) Menyokong investasi modal pemerintah maupun swasta di kawasan Asia untuk tujuan pembangunan

2) Memanfaatkan berbagai sumber dana yang tersedia untuk membiayai pembangunan, dengan memprioritaskan wilayah Asia, berupa berbagai proyek dan program regional yang berdampak positif terhadap pertumbuhan ekonomi. 
3) Membantu negara anggota untuk mengkoordinasikan kebijakan dan rencana pembangunan untuk menyehatkan perekenomian dan menignkatkan ekspansi perdagangan luar negeri.

4) Memberikan bantuan teknis untuk menyiapkan, membiayai, dan melaksanakan program pembangunan.

5) Bekerja sama dengan PBB dan badan internasional, terutama dengan ECAFE.

6) Melaksanakan kegiatan dan memberikan jasa lain sesuai dengan tujuan ADB.

\section{Kegiatan ADB:}

a. Memberikan fasilitas pinjaman.

b. Kegiatan penyaluran dana ADB terbagi dalam dua kategori utama, yaitu: (1) pemberian fasilitas pinjaman umum, dan (2) pemberian fasilitas khusus. Sumber dana dari ADB dapat dari modal sendiri atau dari pihak luar.

c. Macam pembiayaan yang diberikan ADB: (1) dengan memberikan pinjaman dalam mata uang lokal dan sebagian lagi dalam mata uang asing, (2) memberikan 
fasilitas untuk membiayai pengeluaran lokal suatu proyek, yang dapat dilakukan dengan menyediakan mata uang lokal tanpa harus menjual cadangan devisa negara bersangkutan.

\section{Lembaga 2:}

Pada awal perang dunia 2, para ahli keuangan dari seluruh dunia memandang bahwa setelah perang, dunia akan membutuhkan peraturan mengenai kerja sama internasional untuk memecahkan masalah moneter dan keuangan lainnya.

Pada bulan juli 1944, konferensi finansial PBB di AS membentuk 2 lembaga keuangan internasional:

a) IMF (International Monetary Funds).

b) IBRD (International Bank fo Reconstruction and Development), kemudian dikenal dengan nama World Bank.

Tujuan utama Bank Dunia adalah membantu pembangunan di negara anggota dengan memberikan investasi dana untuk tujuan produktif / menciptakan pertumbuhan perdagangan internasional dalam jangka panjang dengan cara mendorong investasi internasional, yang 
pada gilirannya membantu meningkatkan produktivitas dan standar hidup tenaga kerja.

Bank Dunia hanya akan memberikan pinjaman untuk proyek tertentu yang pada praktiknya adalah bendungan, jalan raya, pembangkit listrik, dan infrastruktur publik lainnya. Bank Dunia akan memastikan bahwa dana pinjaman hanya digunakan untuk pertumbuhan ekonomi, bukan untuk pengaruh politik atau faktor nonekonomi lain.

Pada dasarnya, Bank Dunia memiliki dua macam keanggotaan:

1. IFC (International Finance Corporation). Kegiatannya ditujukan untuk pengembangan sektor swasta di NSB.

2. IDA (International Development Association). Kegiatannya ditujukan untuk pengembangan sektor swasta di NSB, dengan kebijakan bank Dunia yang berfokus pada pengurangan kemiskinan. Program IDA hanya diberikan ke negara miskin yang tidak memiliki kelayakan kredit untuk semuavprogram keuangan Bank Dunia.

Menjadi anggota Bank Dunia merupakan syarat mutlak untuk mendapatkan keanggotaan IFC dan IDA. Namun 
sebagian besar bantuan yang diberikan oleh dua institusi tersebut hanya ditujukan ke negara miskin, dengan syarat yang lebih mudah dari pinjaman yang biasa diberikan bank Dunia.Satu prasarayat bagi setiap negara untuk menjadi anggota Bank Dunia adalah negara tersebut memberikan kontribusi berupa sejumlah "modal" kepada Bank Dunia. Sebelum semua itu terlaksana, negara tersebut harus terlebih dahulu menjadi anggota IMF (International Monetary Fund).

Pada tahun 2018, Bank Dunia memiliki anggota 188 negara anggota, termasuk Indonesia. Bank Dunia memiliki kaitan yang erat dengan PBB. Bank Dunia juga bertugas sebagai agen pelaksana studi kelayakan sebelum penanaman modal dilakukan oleh UNDP.

IMF merupakan badan perwakilan dari Bank Dunia. IMF memfokuskan dirinya pada masalah moneter, sementara Bank Dunia memfokuskan dirinya pada pembangunan perekenomian.

Bank Dunia dapat memberikan pinjaman kepada pemerintah negara anggota atau kepada organisasi pemerintah / swasta yang dijamin oleh pemerintah negara tempat proyek berada. Proyek yang dibiayai harus memiliki 
kriteria layak secara ekonomis dan teknis, dan merupakan prioritas utama dalam pembangunan ekonomi sebuah negara. Proyek tersebut akan terus dipantau oleh Bank Dunia untuk memastikan bahwa pinjaman tidak akan menjadi beban bagi perekenomian negara peminjam.

Umumnya, pinjaman Bank Dunia meliputi sebagian atau keseluruhan jumlah biaya dari proyek yang diusulkan dalam valuta asing atau mata uang lokal negara yang bersangkutan.

\section{Dampak Bantuan Luar Negeri Terhadap Pembangunan}

Bantuan luar negeri memiliki 2 dampak terhadap pembangunan:

1. Jika jangka waktu pinjaman pemerintah negara donor relatif lama, bantuan tersebut akan meringankan beban pembayaran di masa mendatang serta meningkatkan aliran bersih dari sumber luar negeri di masa depan. Hal ini sering disebut dengan istilah nilai hibah.

2. Jika yang memberi donor adalah aliran modal swasta / perusahaan swasta, seringkali bantuan diberikan 
untuk mendukung tujuan mereka di negara NSB. Alasan perusahaan swasta dapat bermotif ekonomi, politik, atau militer.

Bantuan luar negeri juga seringkali digunakan sebagai alat untuk mempengaruhi pemerintah NSB untuk mengubah kebijakan pembangunan sesuai dengan keinginan negara donor. Tidak jarang, negara donor mengubah alokasi bantuan sesuai dengan pergeseran pemikiran dalam pembangunan NSB.

\section{Manfaat Investasi Asing}

Di negara berkembang seperti Indonesia, Undang- undang keselamatan kerja yang berlaku tidak secara otomatis meningkatkan kondisi di tempat kerja, disamping hukuman yang ringan bagi yang melanggar aturan. Meningkatkan standar keselamatan kerja yang lebih baik akan menghasilkan keuangan yang baik.

Serangkaian perundangan NSB berkenaan dengan investasi asing menunjukan keaktifan NSB dalam mencari investor asing. Dengan mengundang investor asing, umumnya NSB mengharapkan 3 garis besar manfaat: 
1. Menciptakan lapangan kerja.

Negara tuan rumah mengundang perusahaan multinasional untuk masuk ke negerinya agar investasi yang mereka tanamkan dapat menciptakan lapangan kerja baru di negaranya. Tetapi pendapat ini secara tegas ditolak beberapa ekonom, dimana mereka menyatakan bahwa terjadinya pergeseran terhadap perusahaan lokal oleh perusahaan multinasional justru mengurangi lapangan kerja di negara setempat.

Beberapa kritik mengenai kehadiran TNC (Trans National Company) bahwa perusahaan ini tidak hanya cenderung untuk mengadakan investasi di sektor padat modal, namu juga cenderung menggunakan teknologi yang lebih padat modal daripada perusahaan lokal.

Di sisi lain, TNC yang berasal dari NSB sendiri malah cenderung menjadi pencipta lapangan kerja yang efektif, meski volume investasi mereka masih relatif kecil.

\section{Alih Teknologi}

Menfaat kedua yang diharapkan adalah proses alih teknologi, keterampilan, dan know how. Informasi mengenai 
alih teknologi diharapkan menunjang pertumbuhan dan produktivitas ekonomi dalam jangka panjang.

Terdapat 3 faktor yang mempengaruhi kemampuan NSB dalam menggali peluang dari investasi asing: (1) kapasitas negara tuan rumah dalam menyerap informasi ditentukan oleh kualitas SDM yang dimilikinya, (2) kemauan TNC dalam mengakomodasi keinginan negara tuan rumah dalam proses alih teknologi, dan (3) kebijakan negara tuan rumah terhadap alih teknologi.

\section{Perolehan Devisa}

Manfaat ketiga adalah memperoleh tabungan dan mendapatkan cadangan devisa. Tetapi dampak investasi TNC terhadap neraca pembayaran telah menjadi sebuah kontroversi. Menurut beberapa studi, banyak TNC yang mengekspor devisa mereka (melalui repatriasi laba) sehingga menyebabkan hilangnya devisa yang seharusnya diperoleh negara tuan rumah.

\section{E. Kebijakan NSB terhadap Investasi}

1. Restriksi 
Kebijakan yang bersifat restriksi dapat berupa prasyarat kinerja, (2) "hukum kejenuhan" / saturation law, dan (3) pengendalian repatriasi laba.

Prasayarat kinerja biasanya ditetapkan untuk setiap industri, misal: bagi TNC yang masuk pada industri otomotif diharuskan menigkatkan kandungan lokal pada otomotif secara progresif. Hal ini dilakukan agar negara memiliki manfaat nyata dari investasi asing tersebut, yaitu lapangan kerja, alih teknologi, dan devisa.

Kebijakan lain yang banyak diterapkan untuk mempercepat alih teknologi adalah tuntutan NSB untuk membentuk usaha patungan / joint ventures. Hal ini dikenal sebagai "hukum kejenuhan". Tujuannya adalah agar mitra lokal dapat memantau dan mempelajari teknologi yang digunakan oleh TNC.

Batasan lain umumnya berupa batas maksimum repatriasi laba pada TNC dan keharusan menginvestasikan kembali sebagian laba ke negara tuan rumah.

2. Insentif 
Bagi para investor asing yang mampu memenuhi prasarat kinerja yang diajukan NSB, biasanya NSB akan mengajukan berbagai insentif, beberapanya adalah tax holidays / insentif pajak lainnya, hak monopoli pasar lokal, dan jaminan bahwa investor dapat melakukan repatriasi laba.

Hak hak monopoli pada pasar lokal bagi investor asing sangat memacu mereka untuk sesegera mungkin melakukan investasi.

Insentif pajak merupakan dorongan yang paling banyak diberikan ke TNC. Ragam insentif sendiri ada banyak sekali, tetapi yang paling umum adalah pemberian tax holidays. Dengan tax holidays, pemerintah NSB memberikan pembebasan pajak pendapatan selama beberapa tahun ( umumnya 3 sampai 6 tahun) bagi TNC yang baru beroperasi di negaranya.

\section{F. Sumber Pinjaman Luar Negeri Bagi Pembangunan di Indonesia}

Sumber 1: The Inter - Governmental Group on Indonesia (IGGI) 
Sejak 1966, pemerintah Orde Baru mengambil langkah kebijakan stabilisasi, reorganisasi, dan rehabilitasi terhadap sistem perekenomian sebagai basis penting pertumbuhan ekonomi. Dalam bidang keuangan, pemerintah Orde Baru berusaha memperbaikinya dengan menyelesaikan hutang keuangan Orde Lama, menarik investasi asing, serta meminta bantuan keuangan dan teknik ke badan internasional.

Pertemuan pemerintah Indonesia dan beberapa lembaga internasional dikoordinasikan dalam satu wadah kerjasama yang disebut the international governmental Group on Indonesia (IGGI). Dalam perkembangannya, IGGI tumbuh sebagai forum pertemuan konsultatif negara negara donor dan lembaga keuangan internasional dengan pemerintah negara Indonesia dalam membantu mengatasi permasalan ekonomi.

Perekonomian Indonesia di tahun 1966 menghadapi masalah pokok yang sangat serius, yaitu:

1. Krisis ekonomi dan inflasi yang sangat tinggi, krisis neraca pembayaran, akumulasi utang yang tak terbayar, dan keadaan ekonomi yang kacau. 
2. Krisis ekonomi yang menyebabkan hampir tidak ada pembangunan ekonomi, birokrasi, sistem pajak, perbankan, dan perdagangan luar negeri yang berjalan dengan baik.

Dari hasil konsultasi IGGI, disadari bahwa penanganan secara bilateral akan sangat sulit mengatasi krisis yang dihadapi Indonesia dan satu satunya alternatif yang terbaik adalah dengan koordinasi bersifat internasional.

Pemerintah Belanda mengambil inisiatif untuk memulai dan menjadi tuan rumah negara negara kreditur internasional. Pada pertemuan tersebut, negara kreditur bersepakat menghentikan pembayaran hutang Indonesia untuk sementara waktu dan melakukan reschedule pembayaran hutang agar Indonesia dapat menata perekonomiannya dahulu.

Sumber 2 : Consultative Group on Indonesia (CGI)

Pinjaman atau hibah CGI adalah dana yang diterima pemerintah Indonesia dari negara donor CGI. Terdapat dua jenis pinjaman yang diterima pemerintah Indonesia dari CGI: 
1. Pinjaman Bilateral, adalah pinjaman luar negeri yang berasal dari pemerintah suatu negara melalui suatu lembaga keuangan dan/atau lembaga non keuangan yang ditunjuk oleh pemerintah negara yang bersangkutan untuk melaksanakan pemberian pinjaman. Pinjaman Bilateral dapat berbentuk hibah atau dalam bentuk soft loan.

2. Pinjaman Multilateral, adalah pinjaman luar negeri yang berasal dari lembaga internasional dimana Indonesia telah tergabung dalam lembaga tersebut. CGI memberikan pinjaman Multilateral dalam bentuk Mixed Credit (pinjaman lunak dengan fasilitas kredit ekspor)

Sumber 3 : Pinjaman di luar IGGI / CGI

Indonesia juga menerima pinjaman dari negara negara lain yang tidak tergabung pada IGGI / CGI. Negara negara tersebut dikenal dengan sebutan "Petro Dollar", antara lain: Kuwait, Saudi Arabia, Abu Dhabi, Brunei Darussalam, Korea Selatan, Taiwan, dan India.

Alasan klasik yang disebutkan oleh negara negara yang tidak ingin berkontribusi dalam IGGI /CGI adalah bahwa 
hutang pada NSB, salah satunya Indonesia, timbul karena politik imperialis dunia barat, dan mereka tidak ikut bertanggung jawab atas hutang tersebut.

\section{G. Soal Soal}

1. Jelaskan definisi dan jenis bantuan dari luar negeri!

2. Jelaskan mengenai tujuan dan fungsi Asian Development Bank!

3. Jelaskan dua macam keanggotaan World Bank serta jelaskan keuntungan dari keanggotaan tersebut!

4. Jelaskan manfaat dari investasi asing!

5. Jelaskan kebijakan apa saja yang diambil oleh NSB dalam menghadapi investasi asing! 


\section{DAFTAR PUSTAKA}

Arsyad, Lincolin. (2010). Ekonomi Pembangunan. Jogjakarta: STIM YKPN.

Basri, Faisal, (2002). Perekonomian Indonesia: Tantangan Dan Kebangkitan Ekonomi Nasional. Jakarta: Erlangga.

Parjiono, (2018). Kebijakan Multilateral dan Pembangunan Ekonomi di Indonesia. Jakarta: Gramedia

Sanusi, Bachrawi. (2004). Pengantar Ekonomi Pembangunan. Jakarta: Rineka Cipta

Sukirno, Sadono. (2006). Ekonomi Pembangunan; Proses, Masalah, dan Dasar Kebijakan. Jakarta: Kencana Prenada Media

Todaro, Michael. (2000). Pembangunan Ekonomi di Dunia Ketiga. Jakarta: Erlangga. 
BIODATA PENULIS 1

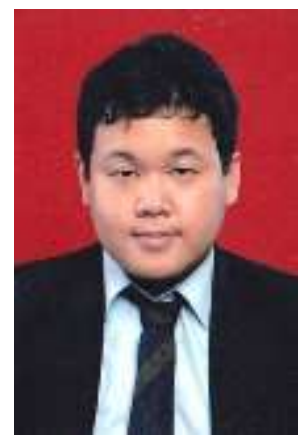

Rizky Eka Febriansah, S.Mb., M.SM. lulus S1 di Program Studi Manajemen Bisnis di Fakultas Manajemen Bisnis Telekomunikasi Universitas Telkom (UTELK) Bandung Tahun 2011. Lulus S2 di Program Magister Science Management Universitas Airlangga (UNAIR) Surabaya Tahun 2015. Saat ini, penulis adalah Dosen Tetap sekaligus menjabat sebagai Kepala Laboratorium periode 2016 - 2018 pada Program Studi Manajemen Fakultas Ekonomi dan Bisnis Universitas Muhammadiyah Sidoarjo. Mengampu mata kuliah Manajemen Sumber Daya Manusia 1, Manajemen Sumber Daya Manusia 2, dan Sistem Informasi Manajemen. Penulis aktif di dunia organisasi, terlibat pada Himpunan Pengusaha Muda Indonesia (HIPMI) dan Forum Manajemen Indonesia (FMI). Penulis juga aktif dalam menulis jurnal ilmiah dan pernah tampil pada 3 konferensi pada kurun waktu 2016 - 2017, 2 konferensi nasional dan 1 konferensi Internasional. 
BIODATA PENULIS 2

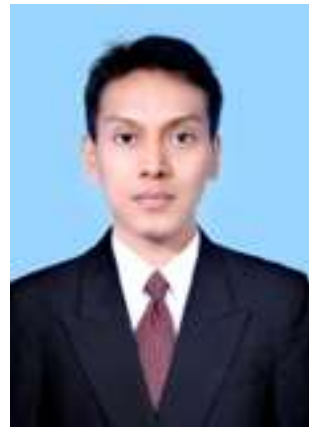

Detak Prapanca, SE, MM. Lahir pada 15 Pebruari 1984 di Bangkalan, merupakan anak ke 3 dari 6 bersaudara. Menempuh S1 nya pada IImu Ekonomi Pembangunan Fakultas Ekonomi Universitas Muhammadiyah Malang dan S2 nya pada Magister Manajemen pada Universitas Muhammadiyah Malang. Penulis merupakan dosen tetap Universitas Muhammadiyah

Sidoarjo. Sebelum memutuskan untuk berkarir sebagai pengajar pada akhir tahun 2017, penulis pernah memiliki karir pada Dinas Pengelolaan Keuangan dan Kekayaan Daerah Kabupaten Katingan Kalimantan Tengah dan pada Bank BTPN Syariah. 
I8BN 978-602 0914768

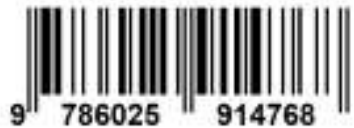

